\title{
Sinomacrops bondei, a new anurognathid pterosaur from the Jurassic of China and comments on the group
}



Anurognathids are an elusive group of diminutive, potentially arboreal pterosaurs. Even though their monophyly has been well-supported, their intrarelationships have been obscure, and their phylogenetic placement even more. In the present work, we present a new genus and species from the Middle-Late Jurassic Tiaojishan Formation, the third nominal anurognathid species from the Jurassic of China. The new species provides new information concerning morphological diversity for the group. Furthermore, we provide a new phylogenetic analysis incorporating into a single data set characters from diverging phylogenetic proposals. Our results place them as the sister-group of Darwinoptera + Pterodactyloidea, as basal members of the Monofenestrata. 


\section{Sinomacrops bondei, a new anurognathid pterosaur}

\section{2 from the Jurassic of China and comments on the}

3 group

4 Xuefang Wei ${ }^{1,2,3}$, Rodrigo V. Pêgas ${ }^{4}$, Caizhi Shen ${ }^{5}$, Yanfang Guo ${ }^{5}$, Waisum Ma ${ }^{6}$, Deyu Sun ${ }^{7}$, 5 Xuanyu Zhou ${ }^{8,9 *}$

7 1. Key Laboratory of Stratigraphy and Palaeontology, Ministry of Natural Resource, Institute of 8 Geology, Chinese Academy of Geological Sciences, Beijing, China.

9 2. China University of Geosciences, Beijing, China.

10 3. Centre of Cores and Samples of Nature Resources, China Geological Survey, Beijing, China.

11 4. Federal University of ABC, São Bernardo, Brazil.

12 5. Dalian Natural History Museum, Dalian, Liaoning, China.

13 6. School of Geography, Earth and Environmental Sciences, University of Birmingham, 14 Birmingham, United Kingdom.

15 7. Jinzhou Paleontology Museum, Jinzhou, Liaoning, China.

16 8. Department of Natural History Sciences, Hokkaido University, Sapporo, Japan.

Corresponding Author:

Xuanyu Zhou

Hokkaido University, Sapporo, Japan

Email address: xyzhou@elms.hokudai.ac.jp

\section{Abstract}

Anurognathids are an elusive group of diminutive, potentially arboreal pterosaurs. Even though their monophyly has been well-supported, their intrarelationships have been obscure, and their phylogenetic placement even more so. In the present work, we present a new genus and species concerning morphological diversity for the group. Furthermore, we provide a new phylogenetic analysis incorporating into a single dataset characters from different analyses that have resulted 
31 in diverging phylogenetic proposals. Our results place them as the sister-group of Darwinoptera

32 + Pterodactyloidea, as basal members of the Monofenestrata.

33

34

35

36

\section{Introduction}

Pterosaurs, a group of archosauromorph reptiles of disputed placement (see Renesto \& Binelli 2004, Hone \& Benton 2007, Bennett 2013, Ezcurra et al. 2020), were the first vertebrates known to develop active flight, with a fossil record stretching from the Late Triassic to the K/Pg boundary (Wellnhofer 1991, Andres et al. 2014, Dalla Vecchia 2014). The Anurognathidae are a very peculiar pterosaur group still poorly understood and rather obscure, characterized by a unique morphology and involved in a complex history of uncertainty about their phylogenetic affinities (Hone 2020). Spanning from the Middle Jurassic (Callovian) to the Early Cretaceous (Aptian), anurognathids are small-sized (up to $900 \mathrm{~mm}$ in wingspan) and exhibit short skulls with a diminutive preorbital region, huge orbits and rounded jaws that are wider than long (Bennett 2007, Hone 2020). Due to their short wings with low aspect ratios and their peg-like teeth, these small pterosaurs have been interpreted as aerial insectivores (Bennett 2007, Witton 2008, 2013, Ösi 2011, Habib 2011, Hone 2020), of possible arboreal habits (Ji \& Ji 1998, Bennett 2007, Witton 2013, Lü et al. 2018, Hone 2020).

The Anurognathidae have been defined as a node-based group, as the least inclusive clade containing Anurognathus ammoni and Batrachognathus volans (Kellner 2003, Unwin 2003). Recently, it has been redefined as a branch-based group, englobing all species closer to Anurognathus than to Dimorphodon, Pterodactylus or Scaphognathus (Hone, 2020). So far, this group comprises six nominal species, and is known by 12 specimens from Germany, Kazakhstan, Mongolia, China and North Korea (with a putative $13^{\text {th }}$ one from the USA). The first described one was Anurognathus ammoni, coming from the Tithonian Solnhofen limestones of Bavaria (Döderlein 1923) and being represented by two specimens (Bennett 2007). It was not until the second specimen was described that several aspects of its morphology were clarified, such as the broad wings, the short preorbital region and extensive orbit, the jugal overlying the maxilla, the vertical (or slightly anteriorly inclined) quadrate, the reduced palatal elements, and the short tail lacking filiform processes of the zygapophyses and haemapophyses, convergent with pterodactyloids (Bennett 2007). 
61 The second nominal species was Batrachognathus volans, described from an incomplete

62 skeleton including a partial skull from the Oxfordian-Kimmeridgian Karabastau Formation of

63 Kazakhstan (Riabinin 1948). A second specimen of Batrachognathus volans (Unwin et al.

64 2000), still awaiting a full description, possesses a tail that bears well-developed rod-like

65 processes of the haemapophyses and zygapophyses, and is longer than that of any other anurognathid (Costa et al. 2013). With this discovery, Batrachognathus volans became the first known anurognathid to exhibit a long tail with developed rod-like processes as typical of most non-pterodactyloid pterosaurs (see Costa et al. 2013).

The third anurognathid to be described was Dendrorhynchoides curvidentatus, the first recovered from a Cretaceous deposit, the early Aptian Jianshangou beds of the Yixian Formation (Ji \& Ji 1998). Originally thought of as Barremian, these beds are now viewed as early Aptian in age (see Chang et al. 2009).

Jeholopterus ningchengensis, based on an almost complete skeleton with extensive soft tissue preservation coming from the Daohugou beds near Daohugou (Ningcheng County, Inner Mongolia), was later described as another Cretaceous anurognathid (Wang et al. 2002), on the basis of the now outdated view of the Daouhugou beds as part of the Yixian Formation (Barremian-Aptian). Subsequently, these beds were reinterpreted as part of the Middle-Late Jurassic Tiaojishan Formation. Presently, these rocks have been once more reinterpreted, and are now considered to belong to the Haifanggou/Jiulongshan Formation (Huang 2015, 2016). The locality that has yielded Jeholopterus ningchengensis has been dated as Callovian-Oxfordian (Liu et al. 2006, Gao \& Shubin 2012). A second specimen from the same locality has been regarded as most likely conspecific with Jeholopterus ningchengensis, though a detailed description and a formal taxonomic assessment have not been provided yet (Ji \& Yuan 2002, Witton 2013, Yang et al. 2019).

Later, a second species for the genus Dendrorhynchoides, named D. mutoudengensis, was erected based on an almost complete skeleton from the Mutoudeng locality, Tiaojishan Formation (Lü \& Hone 2012). Recently, a new genus has been erected to accommodate this species: Luopterus, named after the late Prof. Junchang Lü (Hone 2020). Moreover, a second Cretaceous anurognathid was also named recently, Vesperopterylus lamadongensis, known from an almost complete holotype from the late Aptian Jiufotang Formation (Lü et al. 2018). 
91 Indeterminate specimens include IVPP V16728, which stands out as the second specimen with a 92 long tail and developed rod-like processes, similar to Batrachognathus volans (see Costa et al. 93 2013) and unlike all remaining anurognathids. NJU-57003 is another long-tailed specimen from 94 the Mutoudeng locality (Daohugou Beds, Tiaojishan Formation), only preliminarily described 95 (Yang et al. 2019). A relatively complete specimen from the Early Cretaceous of North Korea 96 also awaits description (Gao et al. 2009), as well as a fragmentary specimen comprised of wing

97 elements from the Middle Jurassic (Aalenian/Bajocian) Bakhar deposits of Central Mongolia 98 (Bakhurina \& Unwin 1995). Finally, the poorly-known Mesadactylus ornithosphyos, based on the holotype BYU 2024 (a synsacrum) from the Kimmeridgian-Tithonian Morrison Formation of the USA (Jensen \& Padian 1989), is a potential anurognathid (see Bennett 2007).

101

102

103

104

105

106

107

108

109

110

111

112

113

114

115

116

117

118

119

Pterosaur phylogeny is intricated with controversies, but no other group compares to the Anurognathidae when it comes to uncertainty concerning its placement (Young 1964, Unwin 1992, 1995, 2003, Viscardi et al. 1999; Kellner 2003, Andres et al. 2010, Dalla Vecchia 2014, 2019, Hone 2020). Five cladistic hypotheses based on computed analyses have been presented for the Anurognathidae, wherein they are viewed as: the basalmost pterosaur group (Kellner, 2003); the sister-group of the Novialoidea (Unwin 2003); the sister-group of the Breviquartossa (Dalla Vecchia 2019); scaphognathids, whereby these are the sister-group of the Monofenestrata (Vidovic \& Martill 2017); or the sister-group of the Pterodactyloidea (Andres et al. 2010, 2014). And even though the monophyly of the Anurognathidae has been strongly corroborated (Kellner 2003, Unwin 2003, Bennett 2007, Andres et al. 2010, Dalla Vecchia 2019), its intrarelationships have been poorly explored (Hone, 2020).

This work presents a new fossil coming from the Mutoudeng locality, JZMP-2107500095, representing a new genus and species of long-tailed anurognathid. Despite being crushed to the point of obliterating many details, the specimen is rather complete and provides new information for the group, including the first record of an anurognathid skull exposed in lateral view. In other specimens, the skull is either exposed in internal view, as in the holotype of Anurognathus ammoni (Döderlein 1923, Wellnhofer 1975, Bennett 2007), or dorsoventrally crushed, as in all other specimens that preserve a skull (Riabinin 1948, Ji \& Ji 1998, Bennett 2007, Gao et al. 2009, Lü \& Hone 2012, Lü et al. 2018). 
120 We further review the phylogenetic relationships of the group (both intra and inter), presenting

121 an analysis including all proposed species and a resulting in a new hypothesis for the placement

122 of the group as basal monofenestratans.

\section{Geological setting}

125 The Tiaojishan Formation takes its name from the Tiaojishan Mountain (Mentougou District,

126 Beijing), and was named by Ye (1920). This and the Haifanggou/Jiulongshan Formation have

127 yielded the famous Yanliao Biota in western Liaoning and adjacent regions (Huang 2015, 2016).

128 This biota is well known for the beautiful preservation and abundancy of insects and vertebrate

129 fossils, such as salamanders, feathered dinosaurs, pterosaurs and mammals (Sullivan et al.,

130 2014). The most important localities that yield the Yanliao Biota are Daohugou in Ningcheng

131 County of southeast Inner Mongolia (Haifanggou Fm.), Linglongta of Jianchang County of

132 western Liaoning Province (Tiaojishan Fm.), and Mutoudeng of Qinglong County of northern

133 Hebei Province (Tiaojishan Fm.; Lü et al. 2013, Huang 2015, 2016). From the Haifanggou

134 Formation at Daohugou (Liu et al. 2012), pterosaurs are relatively rare, with Jeholopterus

135 ningchengensis (Wang et al. 2002), Pterorhynchus wellnhoferi (Czerkas \& Ji 2002) and

136 Daohugoupterus delicatus (Cheng et al. 2015). From the slightly younger Tiaojishan Formation

137 at the Linglongta locality, pterosaurs are abundant in number and in diversity (see Sullivan et al.

1382014 for a review), with wukongopterids (Wang et al. 2009, 2010; Lü et al. 2009; Cheng et al.

139 2017), Jianchangopterus (Lü \& Bo 2011), Jianchangnathus (Cheng et al. 2012) and

140 Fenghuangopterus (Lü et al. 2010). From the Tiaojishan Formation at Mutoudeng come

141 Luopterus mutoudengensis (Lü \& Hone 2012; Hone 2020), Qinglongpterus guoi (Lü et al. 2012)

142 and Changchengopterus pani (Lü 2009). It is from the Mutoudeng locality that comes the new

143 specimen herein described (Fig. 1).

144 The Tiaojishan Formation is mainly distributed in the Chengde Basin (Maoniujiao-

145 Xiaoguozhangzi-Jiyuqing Area) in northern Hebei Province. It is around $300 \mathrm{~m}$ thick (Zhang \&

146 Chen, 2015). It is mainly composed of neutral volcanic rock (Zhang \& Chen, 2015). The

147 lithology of the lower member includes dark grey, grey purple trachyandesites, quartz

148 trachyandesites, small trachyandesitic agglomerate, small trachyandesitic ignimbrite (Zhang \&

149 Chen, 2015). The lithology of upper member includes dark grey, burgundy trachyandesites, 
150 trachyandesitic agglomerate, partially containing grayish purple, grayish green sedimentary tuff,

151 tuffaceous conglomerate and tuffaceous sandstone (Zhang \& Chen, 2015).

152 Zhang et al. (2008) analyzed samples of volcanic rock from several typical localities (Luanping

153 Basin, Chengde Basin, Sanshijiazi Basin and Jinlingsi-Yangshan Basin), utilizing LA-ICP-MS

154 Zircon $\mathrm{U}-\mathrm{Pb}$. Their result suggest that the lower limit age of the Tiaojishan Formation should be

155 around $165 \mathrm{Ma}$. Li et al. (2019) analyzed samples of volcanic rock from the bottom of the lower

156 section and andesite from the top of the upper section, utilizing LA-ICP-MS Zircon U-Pb. Their

157 result gave an age range of 170-153 Ma for the Formation as a whole, that is, from the Bajocian

158 until the Kimmeridgian. A specific dating for the strata of the Linglongta locality has been

159 provided by Liu et al. (2012), in order to provide a constrained age range for Linglongta

160 wukongopterid pterosaurs. The bottom and the top of this locality were dated, resulting in an age

161 range of 161-160 Ma (Liu et al., 2012), falling within the Oxfordian (early Late Jurassic).

162 Specific dating under geochemical approaches still lack for the Mutoudeng locality. However,

163 biostratigraphic studies, based mainly on conchostracans, suggest that the Linglongta and

164 Mutoudeng strata are chronocorrelate (Chu et al., 2016).

165

166

Material \& Methods

167

Institutional abbreviations

168

BMNHC, Beijing Museum of Natural History, Beijing, China; BYU, Brigham Young

University Museum of Paleontology, Provo, Utah, USA; IVPP, Institute of Vertebrate

170

Paleontology and Paleoanthropology, Beijing, China; JPM, JZMP, Jinzhou Museum of

171 Paleontology, Jinzhou; NJU, Nanjing University, Nanjing, China.

\section{Computed tomography (CT) scanning}

174 JPM-2012-001 was computed tomography (CT) scanned using a Nikon XTH225ST scanner at 175 the Laboratory of Stratigraphy and Paleontology, Institute of Geology, Chinese Academy of

176 Geological Sciences (IG-CAGS), Beijing, China. The specimen was scanned at $160 \mathrm{kV}$ and 131

$177 \mu \mathrm{A}$. The data set includes 2000 image slices (2000 x 2000 pixels) with a slice thickness of 0.121 
178

179

180

181

182

183

184

185

186

187

188

189

190

191

192

193

194

195

196

197

198

199

200

201

202

203

204

205

206

mm. The data was imported into digital visualization software Avizo (version 9.1) for image processing and visualization.

\section{Phylogenetic Analysis}

Concerning terminal taxa, our phylogenetic analysis is focused on non-pterodactyloid pterosaurs, following previous works that also focused on these forms (e.g. Dalla Vecchia 2009-2019, Andres et al. 2010; Lü et al. 2012). Concerning our character list, we have gathered discrete characters from Vidovic \& Martill (2017), Longrich et al. (2018) and Dalla Vecchia (2019), all of which further encompass data from previous studies (e.g. Kellner 2003, Unwin 2003, Dalla Vecchia 2009, Lü et al. 2009, Wang et al. 2012, Naish et al. 2013, Andres et al. 2014, Britt et al. 2018). Following previous works, we did not employ composite coding (Colless 1985). The character list is available in Supplemental File 1 (a nexus format file for the software Mesquite, containing the data matrix) and Supplemental File 2 (a TNT file ready for executing the analysis, that can also be opened as a txt file).

We did not employ the treatment of continuous data as such (for discussions on the subject see Goloboff et al. 2006, Bardin et al. 2014, Mongiardino-Koch et al. 2015, Vidovic 2018). The original discretized quantitative characters from previous analyses (see our character list) were not modified, except for morphometric characters 270 (humerus/femur length, modified from Kellner, 2003) and 368 (tibia/femur length). Discrete states for the morphometric characters 270 and 368 were categorized (discretized) by using the gap-weighting method (Thiele 1993). In order to optimize the phylogenetic signal, following Bardin et al. (2014), state number was set at 3. The morphometric dataset subjected to gap-weighting is available as Supplemental Table S1. The resulting categorization is presented in Supplemental Table S1 and the data matrix (Supplemental Files 1, 2).Quantitative characters 1, 45, 106, 152, 191, 264, 265, 270, 285, 289, 290, 293, 304, 313, 320, 321, 323 and 362 were treated as ordered. Following other works, all characters were equally weighted (e.g. Fitzhugh 2006).

The analysis was performed using TNT (Goloboff et al. 2018) and was divided in two steps. The first search was performed using New Technology Search (using Sectorial Search, Ratchet, Drift 
207 and Tree fusing, default parameters), with random seed $=0$. Subsequently, using trees from

208 RAM, we performed a Traditional Search swapping (using TBR, collapsing trees after search).

209 The TNT file is available as Supplemental File 2.

210

211

212

Nomenclatural acts

213 The electronic version of this article in Portable Document Format (PDF) will represent a

214 published work according to the International Commission on Zoological Nomenclature (ICZN),

215 and hence the new names contained in the electronic version are effectively published under that

216 Code from the electronic edition alone. This published work and the nomenclatural acts it

217 contains have been registered in ZooBank, the online registration system for the ICZN. The

218 ZooBank LSIDs (Life Science Identifiers) can be resolved and the associated information viewed

219 through any standard web browser by appending the LSID to the prefix http://zoobank.org/. The

220 LSID for this publication is: urn:lsid:zoobank.org:pub:15997DEB-0EF7-40F6-80B0-

221 2C40ED47D43B. LSID for the new genus: urn:lsid:zoobank.org:act:C1268C7D-80AA-4854-

222 93E7-0E60220A05BC. LSID for the new species: urn:lsid:zoobank.org:act:048E9ADE-8C3A-

223 47D4-B074-DCEFA40BDE9A. The online version of this work is archived and available from

224 the following digital repositories: PeerJ, PubMed Central and CLOCKSS.

225

226 Results

227 Systematic Paleontology

228 Pterosauria Owen, 1842

229 Novialoidea Kellner, 2003

230 Breviquartossa Unwin, 2003

231 Monofenestrata Lü et al., 2009

232 Anurognathidae Kuhn, 1937 
Definition. The most inclusive clade containing Batrachognathus volans but not Anurognathus ammoni (Kellner et al. 2010).

237

238

239

240

241

242

243

244

245

246

247

248

249

250

251

252

253

254

255

256

257

258

Synapomorphies. Humeral deltopectoral crest reduced (less wide than humeral shaft; and less wide than proximodistally long), humeral deltopectoral crest subrectangular, ulnar crest of humerus rounded, humeral/femoral length ratio over 1.60, tibial/femoral length ratio over 1.70.

Included species. Batrachognathus volans and Sinomacrops bondei gen. et sp. nov.

Sinomacrops bondei gen. et sp. nov.

Etymology. The generic name is a combination of Sino, macro and ops; which are Ancient Greek for China, large, and eyes/face, respectively. This is in reference to both the large eyes and the broad faces that are typical of anurognathids, and to the Chinese origin of the new species. The specific epithet honors paleontologist Niels Bonde, for his many scientific contributions and being an inspiration for us.

Holotype. JPM-2012-001 (Figs. 2-6).

Locality and horizon. Mutoudeng, Qinglong County of Hebei Province. Daohugou Beds (Callovian-Oxfordian 164-158 Ma) of the Tiaojishan Formation (see Liu et al. 2006a, 2006b, Gao \& Shubin 2012).

Diagnosis. The new taxon exhibits two autapomorphies: first three maxillary alveoli closely spaced, and tibiotarsus twice as long as the femur.

\section{Description}

Generalities. JPM-2012-001 comprises a crushed skeleton (Fig. 2). While the cranium and some cervical vertebrae are exposed in right lateral aspect (Fig. 3), the remaining of the skeleton is exposed in ventral view. The preserved bone tissue exhibits a fragile, brittle condition. In 
259

260

261

262

263

264

265

266

267

268

269

270

271

272

273

274

275

276

277

278

279

280

281

282

283

284

285

286

287

288

consequence, in many regions of the skeleton, fragments of bone tissue have been lost posterior to collection of the specimen. These lost fragments left clear impressions on the matrix, indicating where they were originally present. Lost fragments include mainly the caudal vertebrae, sternum, distal epiphysis of right humerus, proximal epiphyses of right ulna and radius, parts of the left humerus, and most of the left manus.

Micro computed tomography scan resulted in images with only limited resolution. Nonetheless, the images permitted better visualization of some impressions on the matrix (represented by empty spaces on the slices), helping in the identification of some bone limits and extensions. Such was the case of elements of the left wing (humerus epiphysis, radius and ulna, wing metacarpal and first wing phalanx), as well as the right humerus (Fig. 4). CT images did not provide enough resolution for additional data on other skeletal regions.

Soft tissue. The skeleton includes preservation of soft tissue patches. The dorsal margin of the skull is covered by skin impressions that descends onto the neck region (Fig. 3). An irregular patch of soft tissue lateral to the left tibiotarsus suggests that the brachiopatagium extended posteriorly onto the distal region of the crus. A brachiopatagium extending distally on the crus is consistent with what is seen in Jeholopterus ningchengensis (see Kellner et al. 2009) and pterosaurs in general (see Elgin et al. 2011). Another large patch of soft tissue is present medial to the right hindlimb, extending from the femoral region until the distal fifth of the tibiotarsus. This implies in an extensive cruropatagium, though it is not clear if the tail is integrated with it. An extensive cruropatagium can also be found in Sordes pilosus (Unwin \& Bakhurina 1994). Deeper investigation of the soft tissue remains of JPM-2012-001 is beyond the scope of the present contribution and shall be presented elsewhere.

Cranium. The cranium of JPM-2012-001 is exposed in right lateral aspect (Fig. 3). A small pair of bones on the rostral tip of the skull seem to represent an unfused pair of premaxillae. Individually, they comprise basically two processes, one ascending and another one extending posteriorly. This indicates that the fused premaxillae would display a T-shape similar to other anurognathids, as seen in Batrachognathus volans (Riabinin 1948) and Anurognathus (Bennett 2007). The right premaxilla is exposed laterally, while the left one is slightly displaced and exposed in anteromedial aspect. The dorsal process of the premaxilla seems to have extended for no further than half the height of the skull. It contacts an anterior process of the frontal, which is 
289 elongated and thin, as in Anurognathus ammoni (see Bennett 2007). The posterior process of the 290 premaxillae participates on the occlusal jaw margin, and presumably contacted the maxillae, 291 though the bones are slightly displaced and not in natural contact.

292 The maxilla and jugal are fused, with not visible sutures, forming a large bony structure, 293 posterior to the premaxillae. It forms most of the jaw as well as the ventral border of the orbit. 294 The jugo-maxilla structure houses 9 alveoli. The lacrimal process of the jugal is present on the 295 anterior region of this structure. It forms the anteroventral border of the orbit, and the 296 posteroventral margin of the nasoantorbital fenestra. It is incomplete dorsally, but is clearly 297 slender, much higher than long. The nasal and the lacrimal cannot be distinguished.

298 It appears that both frontals are visible: the right one in lateral aspect, and the left one in medial 299 aspect. They are both positioned on the posterodorsal region of the orbit, and take part in the dorsal margin of the skull itself. Their limits are not clear, but the dorsal margin of the right frontal is convex, as is the dorsal margin of the skull in lateral view. Posterior to the right frontal, two bones are tentatively interpreted as the right parietal and a misplaced right opisthotic.

303

304

305

306

307

308

309

310

311

312

313

314

315

316

317

A large bone bearing 9 alveoli forms most of the right upper jaw margin, and is here interpreted as a jugomaxilla complex, similar to the one reported for Anurognathus ammoni where the jugal overlays the maxilla laterally, fusing with it (Bennett 2007). The structure is seen in lateral view, and no sutures can be seen separating jugal from maxilla. The right jugomaxilla seems to be disarticulated from both the quadrate and the premaxilla.

A triangular bone located on the posterior margin of the orbit is tentatively interpreted as the postorbital. If this identification is correct, then the postorbital of Sinomacrops is quite different from that of Anurognathus, which is very slender (and dorsoventrally elongated). Thus, the postorbital of Sinomacrops would be more similar to that of some non-anurognathid pterosaurs such as Dimorphodon or rhamphorhynchids (e.g. Padian 1983, Wellnhofer 1991).

Ventral to the jugomaxilla, a rod-like bone is preserved, adjacent to the impression of another similar rod-like bone. These two rod-like bones are interpreted as either members of the hyoid apparatus, or members of the palate, which is composed of rod-like bones and bony processes (pterygoids, palatines, vomer, ectopterygoids) in Anurognathus ammoni, Jeholopterus ningchengensis and Batrachognathus volans (Riabini 1948, Bennett 2007, Yang et al. 2019). 
318 A partial sclerotic ring is preserved, displaced from its natural position and located ventral to the 319 posterior region of the skull. Though partially preserved, it is complete enough to allow for an 320 estimation of its diameter. It is estimated as $\sim 7 \mathrm{~mm}$, what is close to the estimated diameter of 321 the orbit $(7.5 \mathrm{~mm})$.

322 Mandible. An hemimandible is exposed beneath the skull (Fig. 3). No alveoli can be observed, 323 suggesting that it is the left hemimandible in ventral view. We infer that this hemimandible is complete because its length equals that of the upper jaw. It is only slightly bowed, as in Batrachognathus volans, instead of strongly semicircular as in the jaws of Dendrorhynchoides (Ji \& Ji 1998), Luopterus (Lü \& Hone 2012; Hone 2020), Jeholopterus (Wang et al. 2002), Anurognathus (Bennett 2007) or Vesperopterylus (Lü et al. 2018).

328

329

330

331

332

333

334

335

336

337

338

339

340

341

342

343

344

345

346

Dentition. A single preserved tooth crown is visible, displaced from the jaws and located near the anterodorsal region of the skull (Fig. 3). This tooth is slender and slightly recurved. At least 9 alveoli are present on the right maxilla. The alveoli on the right premaxilla are unclear. The first three maxillary alveoli are closely spaced, with the spacing between them being shorter than their diameter. Posteriorly, the spacing between the subsequent alveoli is subequal to their diameter.

Axial postcranium. Throughout the whole specimen, the vertebrae are highly damaged and details of their anatomy cannot be retrieved (Fig. 2). Still, as the skeleton is almost complete, the lengths of each segment can be estimated, with $23 \mathrm{~mm}$ for the cervical series; $30 \mathrm{~mm}$ for the dorsal series; $11 \mathrm{~mm}$ for the sacral series; and $>36 \mathrm{~mm}$ for the caudal series. The sacral series thus seems to have been elongated, similarly to the condition seen in the possible anurognathid Mesadactylus (see Jensen \& Padian, 1989). The rib of the first sacral is strongly inclined posteriorly, while the rib of the second sacral is less inclined (Fig. 5). This configuration is very similar to that of Mesadactylus (see Jensen \& Padian, 1989). At least 9 pairs of ribs anterior to the sacral region can be seen (Fig. 2), all of which are long and slender, and interpreted as dorsal ribs. This is the same number of dorsal ribs seen in Dendrorhynchoides (Ji \& Ji 1998), Anurognathus (Bennett 2007) and Jeholopterus (Wang et al. 2002). Concerning caudal vertebrae, only three incomplete remains of proximal caudal centra are present, near the sacral region. They are simple, lacking lateral processes. 
347 Forelimb. The scapulae and coracoids of JPM-2012-001 are elongate and slender, as in other 348 anurognathids (e.g. Bennett 2007, Lü et al. 2018). Although fragments of the bone tissue have 349 been lost post-collection due to the brittle nature of the fossil, the remaining impression of the 350 right humerus is quite clear upon close inspection. The deltopectoral crest is subrectangular, as 351 can be better seen on the left side (Fig. 2). As in Batrachognathus volans, the deltopectoral crest 352 of the humerus in JPM-2012-001 was reduced (less wide than proximodistally long, and less 353 wide than humeral shaft) and rectangular in shape. The shape of the ulnar crest is rounded, but it 354 is proximodistally shorter than the deltopectoral crest, as in other anurognathids (Döderlein 1923, 355 Riabinin 1948, Ji \& Ji 1998, Wang et al. 2002, Bennett 2007, Lü \& Hone 2012, Lü et al. 2018, 356 Yang et al. 2019). Incomplete preservation prevents the observation of any details of ulna and 357 radius, although their lengths can be assessed due to their clear impressions on both sides. The 358 right wing-finger preserves complete first, second and third wing phalanges (Fig. 2). The distal 359 region of the third wing phalanx underlies the tibia on the matrix, but the distal end can be seen due to damage on the tibia, revealing the phalanx beneath. The distal end of the third wing phalanx seems to be slightly expanded, indicating a probable articular region for a fourth phalanx, which is not preserved. A free digit with a long, slender proximal phalanx and a robust, strongly recurved ungual is preserved.

364 Hindlimb. Neither femora are fully preserved in terms of bone tissue, though impressions of the 365 lost regions remain on both sides so that their total lengths can be confidently measured (Fig. 2). The right femur is preserved in an approximately natural position relative to the pelvic region, and only part of the proximal region was lost, though an impression remains, showing that it was preserved in articulation with the pelvis. The left femur is displaced, but the proximal region is preserved. The distal region is lost, but an impression also remains. The tibia is quite elongate relative to the femur (Fig. 2), more so than in any other anurognathid (Table 1). On the right crus, tibia and fibula are incompletely ossified, and a gap can be seen between the two (Fig. 2). Despite damage on the proximal region of the right metatarsus, the distal region is wellpreserved. It can be clearly seen that the metatarsal IV is shorter than metatarsals II and III (Fig. 5). A single ungual can be identified on the right pes, which is slightly less robust than the manual unguals (Fig. 6). 
376 Ontogeny. Specimen JPM-2012-001 has not reached osteological maturity, as indicated by the

377 incomplete degree of fusion of the skull bones. The scapula and coracoid seem to be fused,

378 although it remains unclear. Fusion of the extensor tendon process of the first wing phalanx is

379 unclear, as the proximal region of this bone is not well-preserved. A fused puboischiadic plate is

380 present, indicating the specimen must have reached at least "ontogenetic stage 4" of Kellner

381 (2015) and is thus considered a subadult.

382

383

Phylogenetic analysis results

384 Our analysis produced 2 most parsimonious trees, with 1115 steps, CI of 0.456 and RI of 0.668.

385 In the strict consensus tree (Fig. 7), the new species is the sister-group of Batrachognathus

386 volans. The Anurognathinae were recovered with Dendrorhynchoides at the base, plus the newly

387 recognized clade Luopterus + (Jeholopterus + (Anurognathus + Vesperopterylus)).

388

389

390

391

392

393

394

395

396

397

398

399

400

401

402

As in the results from Dalla Vecchia (2019), "Dimorphodon weintraubi" is placed as the sistergroup of a clade containing all other anurognathids. Under the branch-based definition of the Anurognathidae given by Hone (2020), “D. weintraubi” can be considered as a basal anurognathid. For the first time, the Anurognathidae is recovered as the sister group of Darwinoptera + Pterodactyloidea. The synapomorphies are discussed further below.

(n)

\section{Discussion}

\section{Comparisons with other anurognathids}

As detailed above, JPM-2012-001 exhibits a particular feature regarding its dentition: the first three maxillary alveoli are closely spaced, with the spacing between them being shorter than their diameter; while the spacing between the subsequent alveoli is subequal to their diameter. This pattern is unprecedented for anurognathids. In Batrachognathus volans, Dendrorhynchoides curvidentatus, Jeholopterus ningchengensis and Anurognathus ammoni, tooth spacing is constant and larger than tooth diameter (Riabinin 1948, Ji \& Ji 1998, Ji \& Yuan 2002, Bennett 2007). In Vesperopterylus lamadongensis, tooth spacing is also constant, and subequal to (only fractionally 
403 larger than) tooth diameter (Lü et al. 2018). The pattern of tooth spacing in Luopterus

404 mutoudengensis is so far unclear (Lü \& Hone 2012, Hone 2020).

405 Another particular feature is its tibiotarsus/femur length ratio, which is unique within 406 anurognathids (and pterosaurs overall) in that the tibiotarsus is about twice as long as the femur 407 (Table 2, Supplemental Table S1). In Batrachognathus volans, this same ratio is 1.75, while it 408 ranges from 1.22 to 1.47 in other anurognathids (Table 2).

409 Apart from the unique features mentioned above, Sinomacrops bondei further differs from 410 Batrachognathus volans in exhibiting a relatively larger ulnar crest of the humerus (Riabinin 411 1948, Hone 2020). The new species further differs from Anurognathus, Jeholopterus and 412 Vesperopterylus in humerus deltopectoral crest shape (trapezoidal in the latter three taxa) and in 413 exhibiting an elongate tail, longer than the dorsal series (Hone 2020). The new species also 414 differs from Luopterus mutoudengensis and Dendrorhynchoides curvidentatus in the 415 morphology of the deltopectoral crest of the humerus, which is relatively larger and triangular in 416 shape in the latter two (Ji \& Ji 1998, Hone \& Lü 2012, Hone 2020).

\section{Diversity of the Anurognathidae}

419 It has been observed that some aspects of anurognathid morphology did not change from the 420 Middle Jurassic (in the form of Jeholopterus) to the Early Cretaceous (in the form of Dendrorhynchoides; prior to the description of the even younger Vesperopterylus), such as skull 422 shape, palate morphology and dentition (Unwin et al. 2000, Bennett 2007). This has led to the 423 conclusion that the anurognathid bauplan was rather conservative (Unwin et al. 2000, Bennett 424 2007). Nonetheless, several features of anurognathid morphology exhibit some variation, what 425 has been relatively poorly explored so far (Hone 2020).

426 Concerning the particular shape of the anurognathid jaw in dorsal/ventral views, we note that 427 there exists some variation. The roundness of the jaws (both upper and lower) is relatively more 428 pronounced in anurognathines, as can be seen particularly in Anurognathus (Bennett 2007), 429 Jeholopterus (Wang et al. 2002, Ji \& Yuan 2002), Vesperopterylus (Lü et al. 2018) and NJU43057003 (Yang et al. 2019). In these, the arching of the jaws is abrupt and approximately 
431 continuous (Fig. 8), describing a semicircular shape (Fig. 9). In contrast, in Batrachognathus and

432 Sinomacrops, the arching of the jaws is less pronounced and relatively more gradual (Fig. 8),

433 making the jaws rather elliptical instead of semicircular (Fig. 9).

434 Some variation on tooth morphology is also found within anurognathids. The dentition of 435 Anurognathus ammoni is homodont and was referred to as pupiform, given their resemblance to 436 dipteran pupae (Bennett 2007). The only complete tooth preserved in the referred specimen of 437 Anurognathus ammoni is short, has a subcylindrical base and tapers to a sharp end, being only 438 slightly recurved (Bennett 2007). This is very similar to the condition seen in Vesperopterylus 439 lamadongensis, except that in this taxon the teeth are relatively stouter (see Lü et al. 2018).

440 However, the teeth in Jeholopterus ningchengensis, NJU-57003, Dendrorhynchoides 441 curvidentatus and Batrachognathus volans are relatively longer and more recurved. The single 442 tooth visible in the holotype of Sinomacrops bondei is superficially similar to these latter taxa.

443 Luopterus mutoudengensis is unique within anurognathids, having been described as exhibiting a 444 heterodont dentition comprising slender, sharp teeth anteriorly and relatively more robust, short 445 teeth posteriorly (Lü \& Hone 2012). However, recently, Hone (2020) suggested that the 446 purported robust teeth may in fact be bone shards.

447 According to Lü \& Hone (2012) and Hone (2020), a noticeable amount of variation in 448 anurognathids is also expressed through the shape of the deltopectoral crest of the humerus (Fig. 449 10), as follows: rounded for Anurognathus ammoni, alate for Jeholopterus ningchengensis, 450 triangular for Dendrorhynchoides curvidentatus and Luopterus mutoudengensis, and sub451 rectangular (or parallelogram shaped, Hone 2020) for Batrachognathus. However, in the 452 holotype of Anurognathus, the structure is not rounded, but trapezoidal (Döderlein 1923, 453 Wellnhofer 1991). Despite not clearly depicted as such in the line-drawings, the humeral 454 deltopectoral crest of the second specimen of Anurognathus was also explicitly described as 455 trapezoidal (see Bennett 2007), and is probably relatively smaller due to allometric growth. In 456 Vesperopterylus, the deltopectoral crest of the humerus is also trapezoidal, very similar in shape 457 to Anurognathus (see Lü et al. 2018). In the North Korea specimen, the deltopectoral crest of the 458 humerus seems to be trapezoidal as well (Gao et al. 2009). Furthermore, even though the "alate" 459 condition seen in Jeholopterus is unique to it, it is still very similar to the trapezoidal conditions 460 of Anurognathus and Vesperopterylus, differing only in being longer and more curved - they are 
461 thus all coded as "trapezoidal" in our analysis (see Supplemental Information). Concerning other

462 anurognathids, NJU-57003 is similar to Dendrorhynchoides and Luopterus in exhibiting a

463 subtriangular deltopectoral crest of the humerus (Yang et al. 2019). In the holotype of

464 Sinomacrops bondei, the impression of the deltopectoral crest of the humerus reveals it was

465 subrectangular in shape, being similar to that of Batrachognathus volans, but different in that it

466 is relatively shorter and that its distal margin is even straighter than in B. volans (Fig. 10A-B).

467 Sinomacrops and Batrachognathus are further unique in exhibiting deltopectoral crests that are

468 reduced in size, being less wide than the humeral shaft, and less wide than proximodistally long

469 (Fig. 10A-B).

470 Still concerning the proximal region of the humerus, considerable variation can also be found in

471 the shape of the ulnar crest. In Batrachognathus volans and Sinomacrops bondei, the distal

472 margin of the ulnar crest is rounded (Fig. 10A-B). In Dendrorhynchoides curvidentatus, it is

473 slightly more prominent, subtriangular (Fig. 10). In Jeholopterus, it is particularly reduced, and

474 is also prominent (Fig. 10D). In Anurognathus and Vesperopterylus, it is relatively elongated and

475 oriented obliquely to the humeral shaft (Fig. 10E-F).

476 Another interesting variation seen within anurognathids concerns the length of their caudal series

477 and the morphology of their caudal vertebrae (Lü \& Hone 2012, Costa et al. 2013, Jiang et al.

478 2014). Batrachognathus and the indeterminate specimens IVPP V16728 and NJU-57003 exhibit

479 the typical non-pterodactyloid condition, with long tails (longer than femur length) and caudal

480 vertebrae bearing long filiform processes of the zygapohyses and haemapophyses (Costa et al.

481 2013, Jiang et al. 2014, Yang et al. 2019). Luopterus mutoudengensis exhibits a relatively short

482 caudal series, that is shorter than the dorsal series and equals 0.85 the femur length (Lü \& Hone

483 2012). As for caudal vertebrae morphology, Luopterus was reported to bear filiform processes

484 interpreted as haemapophyses (Lü \& Hone 2012). Jiang et al. (2014) have suggested that

485 Luopterus mutoudengensis possessed processes produced by both the zygapophyses and

486 haemapophyses, and we agree this is rather likely. In our matrix, the haemapophyses processes

487 are coded as present and the zygapophyses processes as "?" until a first-hand reassessment of the

488 specimen is provided. In Jeholopterus (both specimens), the tail is most likely shorter than the

489 femur, though details of vertebral morphology cannot be assessed (Wang et al. 2002, Ji \& Yuan

490 2002, Jiang et al. 2014, Yang et al. 2019). Finally, Anurognathus and Vesperopterylus possess

Peer] reviewing PDF | (2020:10:53890:2:0:NEW 25 Feb 2021) 
491 quite shortened tails (accounting for under 60\% the femur length) and caudal vertebrae without

492 any filiform processes, in a homoplastic condition relative to the Pterodactyloidea (see Jiang et 493 al. 2014). In Sinomacrops bondei, even though the total extent of the caudal series is uncertain, 494 the preserved impression indicates it was longer than the femur - in fact, longer than the entire 495 hindlimb.

496

497 Intrarelationships of the Anurognathidae

498 Our phylogenetic analysis places Sinomacrops bondei alongside Batrachognathus volans

499 forming the Batrachognathinae, separately from the clade containing all other Chinese 500 anurognathids plus Anurognathus ammoni (the Anurognathinae as herein defined). Five

501 synapomorphies support Batrachognathinae in our analysis: char. 269(2), humeral/femoral length 502 proportion (over 1.6); char. 271(0) the width of the humeral deltopectoral crest (reduced, less 503 wide than proximodistally long), char 272(3), the shape of the deltopectoral crest

504 (subrectangular); char. 280(2), the shape of the ulnar crest of the humerus (rounded); and char. $505367(2)$, the tibia/femur length proportion (over 1.7).

506 The Anurognathinae would be composed of, according to our results, Dendrorhynchoides 507 curvidentatus, Luopterus mutoudengensis, Jeholopterus ningchengensis, Anurognathus ammnoni 508 and Vesperopterylus lamadongensis. These taxa share the following synapomorphies: char. 30(2) 509 the semicircular arching of the jaws, distinct from the elliptical one seen in batrachognathines, 510 char. 244(1) caudal series shorter than the dorsal series, char. 275(1) deltopectoral crest subequal 511 to humeral head in size, and char. 310(5) pteroid curved and subparallel-sided (Andres et al. 512 2014).

513 The non-monophyly of the genus Dendrorhynchoides encompassing $D$. curvidentatus plus $D$. 514 mutoudengensis (Lü \& Hone 2012) is corroborated here, which is consistent with Wu et al. 515 (2017) and Hone (2020). Luopterus mutoudengensis is recovered as the sister-group of the 516 Jeholopterus-Anurognathus-Vesperopterylus clade, with which it shares char. 378(0), a straight 517 last phalanx of pedal digit V (whereas this phalanx is curved in Dendrorhynchoides 518 curvidentatus). The straight condition is a synapomorphy joining these taxa, while the curved 519 condition is plesiomorphic for anurognathids and present at the base of the Novialoidea, as seen 
520 in Campylognathoides, "Dimorphodon weintraubi”, Changchengopterus pani and

521 wukongopterids (Clark et al. 1998, Lü 2009, Padian 2008a,b, Wang et al. 2009, 2010).

522 The clade composed of Jeholopterus ningchengensis, Anurognathus ammoni and

523 Vesperopterylus lamadongensis is supported by three synapomorphies: char. 272(1)

524 deltopectoral crest of the humerus trapezoidal and broad, char 241(0) caudal vertebrae lacking

525 filiform zygapophyses, and char. 242(0) caudal vertebrae lacking filiform haemapophyses. The

526 sister-group relationship between Anurognathus ammoni and Vesperopterylus lamadongensis is

527 supported by one synapomorphy: char. 271(2), the complete loss of mid-cervical ribs.

528 Previous analyses had recovered disparate results. The results of Wang et al. (2005), derived 529 from the matrix of Kellner (2003), indicated a basal position for Anurognathus ammoni, as the 530 sister-group of a trichotomy comprising Batrachognathus volans, Jeholopterus ningchengensis 531 and Dendrorhynchoides curvidentatus, which thus comprised the Batrachognathinae according 532 to this topology. The relationship between Batrachognathus volans, Jeholopterus ningchengensis 533 and Dendrorhynchoides curvidentatus was based on the following synapomorphy: a very large 534 humerus, with a humeral/femoral length proportion over 1.40 (Kellner 2003, Wang et al. 2005).

535 This ratio (humeral/femoral length proportion) equals 1.2-1.25 for Anurognathus ammoni, 1.43 536 for Dendrorhynchoides curvidentatus, 1.52-1.55 for Jeholopterus ningchengensis, and 1.93 for 537 Batrachognathus volans (Table 2). As such, it can be seen that the value for Dendrorhynchoides 538 curvidentatus and Jeholopterus are not that large, not quite close to Batrachognathus but actually 539 closer to the one found in Anurognathus. Furthermore, all anurognathids subsequently described 540 exhibit such ratios under 1.40: Vesperopterylus lamadongensis (1.35) and Luopterus 541 mutoudengensis (1.28). Thus, all other anurognathid specimens, irrespective of their ontogenetic 542 stage, exhibit a humeral/femoral length ratio between 1.2 and 1.55 (Table 2), except for the 543 holotypes of Sinomacrops bondei (1.77) and Batrachognathus volans (1.93). In order to better 544 investigate the informative value of this morphometric character, we categorized it into discrete 545 states by subjecting a comprehensive morphometric dataset for pterosaurs (see Supplemental 546 Table 1) to a gap-weighting analysis using the software PAST (see Material and Methods). As a 547 result, we found the following categories: humerus/femur length ratio up to 0.6 (state 0 ), over 0.6 548 and under 1.6 (state 1), and equal to 1.6 or over (state 2 ). We found state 2 to correspond to a 
549 synapomorphy for the clade Sinomacrops + Batrachognathus, being exclusive for these two taxa 550 among pterosaurs except for “Huaxiapterus” corollatus (Supplemental Table 1).

551 In the analysis by Wu et al. (2017), a polytypic genus Dendrorhynchoides (encompassing $D$.

552 curvidentatus and D. mutoudengensis) was not recovered as monophyletic. Dendrorhynchoides 553 curvidentatus fell at the base of the group, while Luopterus mutoudengensis fell as the sister554 group of Batrachognathus volans. In this analysis (Wu et al. 2017), the clade comprising all 555 other anurognathids to the exclusion of $D$. curvidentatus was supported by one synapomorphy: a 556 fifth pedal digit phalanx 2 straight, instead of curved as in D. curvidentatus. This bone is clearly 557 curved in D. curvidentatus (see Ji \& Ji 1998) and straight in Luopterus mutoudengensis, 558 Anurognathus ammoni and Jeholopterus ningchengensis (Wang et al. 2002, Bennett 2007, Lü \& 559 Hone 2012), however, it is unknown in Batrachognathus volans (see Riabinin 1948), as well as 560 in Sinomacrops bondei, and thus is not informative concerning the position of Batrachognathus.

561 More recently, in the analysis of Longrich et al. (2018), also derived from Andres et al. (2014), 562 the results recovered Anurognathus ammoni as the sister-group of Jeholopterus ningchengensis, 563 with Dendrorhynchoides curvidentatus as the next successive sister-group, and then

564 Batrachognathus volans at the base of the group. Luopterus mutoudengensis was not included in 565 that analysis. Such topology is compatible with the one presented here, which differs only by the 566 inclusion of Luopterus, Vesperopterylus and Sinomacrops.

\section{Phylogenetic placement of the Anurognathidae}

569

570

571

572

573

574

575

576

Previous works. The interrelationships of anurognathids have been even more obscure than their intrarelationships. Anurognathids have been included in tens of computed phylogenetic analyses, although the cladistic hypotheses concerning their placement can be narrowed down to a total of five (Fig. 11).

In the analysis presented by Kellner (2003), the Anurognathidae have been interpreted as the basal-most known pterosaur lineage (Fig. 11A), as the sister-group of a clade containing all other pterosaurs. This result was reproduced by other workers (Bennett 2007, Lü et al. 2018). As anurognathids span from the Callovian to the Aptian, this placement would imply in an extensive 
577 ghost lineage, as the pterosaur record dates back to the Carnian-Norian (see Kellner 2003). Later

578 versions of this matrix including darwinopterans preserve the same position for the

579 Anurognathidae (e.g. Wang et al. 2009). More recent versions of this data set focus solely on

580 eupterodactyloids and do not contain a comprehensive number of non-pterodactyloids (e.g.

581 Wang et al. 2012, Holgado et al. 2019, Pêgas et al. 2019).

582 The analyses of Unwin $(1992,1995,2003)$ recovered anurognathids as the sister-group of the

583 clade Campylognathoides + Breviquartossa (=Rhamphorhynchidae + Pterodactyloidea), which is

584 equivalent to the Novialoidea sensu Kellner (2003) (Fig. 10B). Recent versions of this matrix,

585 covering further non-pterodactyloids (including darwinopterans), preserve the same position for

586 the Anurognathidae (e.g. Codorniu et al. 2016). However, it is interesting to observe that Unwin

587 (2003) also discussed the possibility that anurognathids were, in fact, the sister-group of the

588 Pterodactyloidea, although the strict consensus tree ultimately favored their interpretation as the

589 sister-group of the Novialoidea. Unwin (2003) noted that anurognathids shared with

590 pterodactyloids a reduction of the cervical ribs and reduction of the caudal series, and stated that

591 a possible close relationship between them was worthy of further investigation. Possible

592 relationships between anurognathids and pterodactyloids had already been discussed also by

593 Young (1964).

594 The analyses of Dalla Vecchia $(2009,2014)$ recovered Anurognathidae as the sister-group of the 595 Pterodactyloidea, with Rhamphorhynchus as the next successive sister-group. However, these 596 analyses did not include any member of the Darwinoptera (sensu Andres et al. 2014). More 597 recently, the subsequent analyses by Britt et al. (2018) and Dalla Vecchia (2019), which are 598 more comprehensive (Fig. 11C) and incorporate darwinopterans, have produced a different 599 result, with Anurognathidae being the sister-group of the Breviquartossa (Rhamphorhynchidae + 600 Monofenestrata), and thus within Novialoidea but outside Breviquartossa. A sister-group 601 relationship between the Anurognathidae and the Breviquartossa was also proposed previously 602 by Viscardi et al. (1999).

603 Under the hypothesis first put forward by Andres et al. (2010), the Anurognathidae are 604 monofenestratans and are closer to pterodactyloids than darwinopterans and rhamphorhynchids 605 (Fig. 11D), thus being comprised within the Breviquartossa and the Monofenestrata. This 
606 proposition thus echoed the suspicion put forward by Unwin (2003) that anurognathids could, 607 perhaps, be closely related to pterodactyloids; as well as the past results from Dalla Vecchia 608 (2009, 2014) that were later modified (Britt et al. 2018, Dalla Vecchia 2019).

609 The most recent hypothesis was put forward by Vidovic \& Martill (2017), whose phylogenetic 610 analysis recovered the Anurognathidae as a clade comprised within Scaphognathidae (Fig. 11E). 611 Similar to the proposal of Dalla Vecchia (2014, 2019), this hypothesis also places anurognathids 612 within breviquartossans and outside the Monofenestrata. However, Vidovic \& Martill (2017) 613 expressed concerns about this result for anurognathids, noting that " $[t]$ heir deeply nested 614 placement within Scaphognathidae is likely to be due to a lack of transitional-morphs combined 615 with their paedomorphism" (Vidovic \& Martill 2017, p. 9). They further noted that " $[t] h e$ 616 paedomorphic characters exhibited by anurognathines (e.g. reduced rostrum length, large orbit, 617 deep skull, shorter caudal vertebrae) might be the reason some researchers (e.g. Kellner 2003; 618 Wang et al. 2009) find them as the most basal taxa in Pterosauria" (Vidovic \& Martill 2017, p. $6199)$.

620 It is worth noticing that anurognathids have also been regarded as possibly related to 621 Dimorphodon (Kuhn 1967, Wellnhofer 1978), based mainly on similarities in skull shape (high 622 skull with a convex dorsal margin in lateral view, and a subvertical quadrate). No computed 623 phylogenetic analyses have recovered a close relationship between dimorphodontids and 624 anurognathids, so far.

625 In summary, among all proposed hypotheses, three of them converge in recognizing a clade that 626 includes Rhamphorhynchidae, Anurognathidae, Darwinoptera and Pterodactyloidea (Andres et 627 al. 2010, Vidovic \& Martill 2017, Dalla Vecchia 2019), though disagreeing on the relationships 628 between these subgroups. Two hypotheses (Andres et al. 2010; Vidovic \& Martill 2017) 629 converge in recovering anurognathids as members of the Breviquartossa. Only the phylogenetic 630 analyses of Andres et al. (2010) found support for the monofenestratan nature of anurognathids, 631 although, prior to the discovery of darwinopterans, Unwin (2003) had already expressed some 632 consideration towards anurognathids being the most closely related group to pterodactyloids.

633 Present work. Our dataset combines discrete characters coming from previous contributions 634 (Kellner 2003, Unwin 2003, Dalla Vecchia 2009, 2019, Andres et al. 2010, 2014, Vidovic \& 
635 Martill 2017). According to the present results, anurognathids are basal monofenestratans, and 636 thus are also members of the Novialoidea and of the Breviquartossa. As our results have 637 produced a novel topology, this warrants some discussion.

638 According to our results, anurognathids exhibit the following synapomorphies of the 639 Novialoidea:

640 Character 192(0). Dentition, variation in crown shape along the upper jaw: absent; and char. 641 193(0) for the lower jaw (Unwin 2003, char. 19; Dalla Vecchia 2019 char. 37, and char. 38 for 642 the lower jaw). Remarks: the secondary loss of heterodonty (which is present in basal pterosaurs) 643 had already been recovered previously as a synapomorphy of the Novialoidea (Andres et al. 644 2014, Dalla Vecchia 2014, 2019).

645 Character 340(1). Postacetabular process of the illium length: shorter than preacetabular process 646 (Vidovic \& Martill 2017, char. 212). This feature had already been recovered as a synapomorphy 647 of the Novialoidea (Vidovic \& Martill 2017). It can be seen in Dendrorhynchoides (Ji \& Ji 648 1998), Jeholopterus (Wang et al. 2002) and Anurognathus (Bennett 2007).

649 Character 380(2). Pedal digit V, phalanx 2, length: shorter than preceding phalanx (Vidovic \& 650 Martill 2017, char. 195). This feature is primitive for novialoids as seen in Campylognathoides 651 (Padian 2008b), Sordes (Unwin \& Bakhurina 1994), Scaphognathus (Bennett 2014), 652 darwinopterans (Wang et al 2010) and pterodactyloids (see Vidovic \& Martill 2017). It is present 653 in Jeholopterus and Luopterus (Wang et al. 2002, Hone \& Lü 2012), although it is reversed in 654 Dendrorhynchoides and Anurognathus (Ji \& Ji 1998, Bennett 2007).

655 Anurognathids further share with the Breviquartossa the following synapomorphies:

656 Character 48 (1). Premaxilla extending to orbit, but no further. This feature had already been 657 recovered as a synapomorphy of the Breviquartossa by Unwin (2003). This feature can be seen 658 in Anurognathus (Bennett 2007).

659 Character 147(1). Mandible, surangular eminence: absent (Unwin 2003, char. 16). Remarks: the 660 secondary loss of this feature had already been considered a synapomorphy of the Breviquartossa 
661 (Unwin, 2003). The feature is absent in Anurognathus ammoni (Bennett 2007) and cannot be 662 assessed in other species.

663 Character 179(2). Dentition, distal teeth, spacing relative to successive teeth: more than diameter 664 of teeth (Andres et al. 2014). This character had already been recovered as a synapomorphy of 665 the Breviquartossa (anurognathids included) by Andres et al. (2014).

666 Character 284(1). Humerus, shaft, cross-section: tapered (Andres et al. 2014). Remarks: this 667 feature, as opposed to a subcircular cross-section of the humeral shaft, has already been 668 recovered as a synapomorphy of the Breviquartossa, anurognathids included (Andres et al. 669 2014).

670 Character 368(1). Fibula, relative length: shorter than tibia (Dalla Vecchia 2009 char. 68, 671 modified from Unwin 2003 char. 8). Remarks: this feature has already been recovered as a 672 synapomorphy of the Breviquartossa, including anurognathids, by Dalla Vecchia (2009).

673 Char. 373(2). Metatarsals, relative length of metatarsal IV: shorter than metatarsals I-III (Unwin 674 2003, char. 21). This feature has already been recovered as a synapomorphy of the 675 Breviquartossa, and the clade name actually derives from this feature (Unwin 2003). In 676 anurognathids, this feature can be seen in Vesperopterylus and Jeholopterus, although metatarsal 677 IV is only slightly shorter than metatarsal III (by, approximately, the width of their diaphyses; 678 Fig. 12). The length difference is thus less conspicuous than in Rhamphorhynchus or 679 Scaphognathus (Wellnhofer 1975a, 1978), but similar to that seen in Sordes (Wellnhofer 1978), 680 Darwinopterus (Lü et al. 2009), Pterodactylus antiquus or Diopecephalus kochi (Wellnhofer 681 1970, 1978). The feature is lost in Anurognathus, in which metatarsals I-IV are subequal in 682 length (Bennett 2007).

683 Character 378(1). Pedal digit V, phalanx 2, shape: curved (Kellner 2003, char. 74). Remarks: 684 primitively, this phalanx is straight, as seen in non-breviquartossans such as Campylognathoides 685 (Wellnhofer 1978, Padian 2008b), Dimorphodon (Padian 1983), and Triassic forms (Dalla 686 Vecchia 2014). The phalanx is curved in rhamphorhynchids (Wellnhofer 1975, 1978, Lü et al. 687 2012, Hone et al. 2012), Dendrorhynchoides (Ji \& Ji 1998) and Kunpengopterus (Wang et al. 688 2010, Cheng et al. 2017), and changes to "bent, angled" (state 2 of same character) in some taxa 
689 such as Dorygnathus, Scaphognathus and Darwinopterus (Andres et al. 2014, Vidovic \& Martill 690 2017, Dalla Vecchia 2019), and reverses to "straight" (state 0) in the Luopterus- Jeholopterus691 Anurognathus clade, in which this phalanx is straight (Wang et al. 2002, Lü \& Hone 2012, 692 Bennett 2007, Andres et al. 2014).

693 Our analysis has also recovered the Digibrevisauria, coined by Vidovic \& Martill (2017) for a 694 clade that comprises the Scaphognathidae and the Monofenestrata, to the exclusion of 695 rhamphorhynchids. Anurognathids show the following features that were recovered as 696 synapomorphies of the Digibrevisauria: 236(1) proximal caudal vertebrae lack distinct lateral 697 processes; 275(2) humerus deltopectoral crest not as long as the humeral head is wide (seen in 698 Sinomacrops and Batrachognathus, reversed to state 1 in the clade containing the remaining 699 anurognathids); 313(1) metacarpal IV lacks a crista metacarpi; 375(1) phalanges of pedal digit 700 IV unequal in length with the distal phalanx larger than all those preceding it, and 376(1) 701 phalanges 2 and 3 of pedal digit IV are squared or shorter than they are wide (Vidovic \& Martill, 702 2017).

703 Within digibrevisaurians, anurognathids were recovered as basal monofenestratans. The 704 Monofenestrata have been phylogenetically defined by Andres et al. (2014) as a synapomorphy705 based clade, defined by the presence of a confluent nasoantorbital fenestra synapomorphic with 706 the one seen in Pterodactylus antiquus. In summary, considering the interpretation put forward 707 by Andres et al. (2010) that anurognathids possess a nasoantorbital fenestra (corroborated here), 708 this would mean that the clade Anurognathidae + (Darwinoptera + Pterodactyloidea) corresponds 709 to the Monofenestrata. According to our results, thus, anurognathids are basal monofenestratans. 710 The Monofenestrata were recovered based on the following 4 features:

711 Character 15(1): Confluent nasoantorbital fenestra. Remarks: most workers have coded a 712 confluent nasoantorbital fenestra as absent for anurognathids (Kellner 2003, Unwin 2003, 713 Bennett 2007, Lü et al. 2018, Vidovic \& Martill 2018), except for Andres et al. (2010, 2014) and 714 Dalla Vecchia (2019). Due to the extremely reduced preorbital region and the small absolute size 715 of anurognathids, investigation of their preorbital fenestration is indeed difficult. In most

716 specimens, the situation cannot be confirmed, such as the holotypes of Jeholopterus 717 ningchengensis, Dendrorhynchoides curvidentatus, Luopterus mutoudengensis and 
718 Vesperopterylus lamadongensis, and also the specimen NJU-57003. The only specimen for

719 which a skull element was tentatively interpreted as an ascending process of the maxilla (and

720 thus a bony bar effectively separating naris and antorbital fenestra, as two distinct openings) is

721 the second specimen of Anurognathus ammoni (Bennett 2007). The identification of this process

722 has been reviewed and challenged by Andres et al. (2010), who argued that the purported

723 process could not be unequivocally identified as an ascending maxillary process separating the

724 nares from the antorbital fenestra, as it could only be seen on the right side, was a faint

725 impression, and was displaced, so that even its natural orientation cannot be unambiguously

726 assessed. Based on its rough location and shape, we offer a tentative interpretation for it as a

727 palatal element. Andres et al. (2010) further noted that there are two previously described

728 anurognathid specimens in which the preorbital region is well preserved and the ascending

729 processes of the maxilla is absent on both sides: the holotype of Batrachognathus and CAGS IG

730 02-81 (see Riabinin 1948, Ji \& Yuan 2002, Andres et al. 2010, Yang et al. 2019, and also Fig.

731 13). In accordance, in the small preorbital region of Sinomacrops, only a single opening is

732 present. We thus favor the interpretation of Andres et al. (2010) that a nasoantorbital fenestra is

733 present in anurognathids (Fig. 13).

734 Character 95(1). Jugal, lacrimal process, subvertical. Remarks: this feature has already been

735 recovered as a synapomorphy of a clade containing Monofenestrata + Sordes (Andres et al.

736 2014). In the present analysis, we coded this character as "anteriorly inclined" (state 0 ) for

737 Sordes (as in the dataset from Vidovic \& Martill 2017), so that the feature is restricted to the

738 Monofenestrata.

739 Character 216(1) Atlantoaxis fusion. Remarks: this feature has already been recovered as a

740 synapomorphy of the Monofenestrata, including anurognathids (Andres et al. 2014). This feature

741 is present in Anurognathus (Wellnhofer 1975a, Bennett 2007).

742 Character 221(1). Mid-cervical vertebrae, ribs: short. Remarks: as already noticed before (Unwin

743 2003), the reduction of mid-cervical ribs can be seen in anurognathids and pterodactyloids. Short

744 mid-cervical ribs have been reported for Jeholopterus (see Wang et al. 2002) and are absent

745 (state 2 of this same character) in Anurognathus and Vesperopterylus (see Bennett 2007, Lü et al. 
746 2018). The mid-cervical ribs are also short (and quite slender) in the Darwinoptera (Wang et al.

747 2009, 2010, Cheng et al. 2017).

748 Finally, Darwinoptera + Pterodactyloidea is supported by the following features that are absent

749 in anurognathids: char 1(1) elongated skull, over four times skull height (Dalla Vecchia 2019,

750 char. 1), char. 112(1), the craniomandibular joint is located under the orbit (and not posterior to

751 it), char. 230(0) first dorsal rib larger than others (Vidovic \& Martill 2017, char. 236;

752 homoplastic with Eudimorphodon), char. 311(2) pteroid over 2/5 ulnar length (Dalla Vecchia

7532019 char. 70), char. 317(0) metacarpal IV posterior crest absent (Vidovic \& Martill 2017 char.

754 164; present in Dendrorhynchoides, see Ji \& Ji 1998), char. 366(1) femur less than twice the

755 length of metacarpal IV (Kellner 2003 char. 71; homoplastic with Rhamphorhynchini,

756 Eudimorphodon, Fenghuangopterus and Sinomacrops), 370(1) splayed metatarsals (Dalla

757 Vecchia 2009, char.70; homoplastic with rhamphorhynchids, Sordes and Scaphognathus), and

758 char. 375(3) distal and proximal phalanges of pedal digit IV longer than those between

759 (reversing to state 1, proximal phalanx is the largest, in the Pterodactyloidea).

760 In summary, these results provide support for the inclusion of the Anurognathidae within the

761 Breviquartossa and, more specifically, within the Monofenestrata (as in Andres et al. 2010,

762 2014), though not closer to pterodactyloids than darwinopterans. In this way, these results

763 represent a new hypothesis for the position of the group, being somewhat intermediate between

764 the results of Andres et al. (2010) and of Dalla Vecchia (2009, 2019). Still, as well-put by a

765 reviewer (N. Jagieslka), pterosaur phylogeny is a "fluid, ever-expanding field", and as noted by

766 Vidovic \& Martill (2017, p.9), studies of anurognathid phylogeny are hampered by their

767 “aberrant morphology". Thus, much work will be needed before the phylogenetic position of

768 anurognathids stabilizes (hopefully with the discovery of "transitional-morphs"), although the

769 present results do lend support for their interpretation as monofenestratans.

\section{A remark on "Dimorphodon weintraubi"}

772 This is a North American Pliensbachian taxon, represented by a partial skeleton still mostly

773 undescribed (Clark et al. 1989) and awaiting a detailed description. If “D. weintraubi" is taken 
774 into consideration, it is recovered as the immediate sister-group of the clade containing all other 775 anurognathids (Dalla Vecchia 2009, 2014, 2019, present work). If Anurognathidae is considered 776 as a branch-based clade (sensu Hone, 2020; the most inclusive clade containing Anurognathus 777 but not Scaphognathus, Dimorphodon or Pterodactylus), then "D. weintraubi” would be a basal

778

779

780

781

782

783

784

785

786

787

788

789

790

791

792

793

794

795

796

797

798

799

800

801 anurognathid. This relationship is supported in our analysis by two synapomorphies: char. 326(0) first wing phalanx under 0.35 total wing digit length, and char. 331(2) wing phalanx 3 shorter than phalanx 1. According to the results by Britt et al. (2018) and Dalla Vecchia (2019), they also share a boot-like prepubis. " $D$. weintraubi" further exhibits a conspicuously shortened metatarsal IV (Clark et al. 1998), typical of the Breviquartossa.

If this relationship and our new results are correct, then "D. weintraubi" pushes the origin of the Monofenestrata back to the Early Jurassic (Pliensbachian). The Early-Middle Jurassic pterosaur record is rather scanty, and the diversity of monofenestratans during that time might have been higher than previously thought. Such scenario is not that farfetched, given that the sister-group of the Dibigrevisauria, the Rhamphorhynchidae, dates back to the Toarcian. A detailed redescription and reassessment of "D. weintraubi" is of the uttermost importance.

\section{Conclusions}

JZMP-2107500095 represents a new anurognathid, here named Sinomacrops bondei (Fig. 14). It is the second anurognathid from the Tiaojishan Formation, and the first anurognathid specimen to exhibit a skull exposed in lateral view. In our new phylogenetic analysis, it is recovered as the sister-group of Batrachognathus volans, with which it comprises the Batrachognathinae. All other taxa were recovered as closer to Anurognathus. The exclusion of Luopterus mutoudengensis from the genus Dendrorhynchoides is corroborated. Vesperopterylus lamadongensis is recovered as the sister-group of Anurognathus ammoni, with Jeholopterus ningchengensis as their successive sister-group.

Some previous interpretations of anurognathid morphology and systematics have relied on limited available information. With time and new specimens being discovered, new data have been provided and new interpretations were presented. For this reason, each new specimen is 
802 crucial for the understanding of the group. The present information available leads us to interpret 803 anurognathids as basal members of the Monofenestrata, as the sister-group of Darwinoptera + 804 Pterodactyloidea.

805

806

Acknowledgements

807

808

809

810

811

812

813

814

815

816

817

818

819

820

821

822

823

824

825

826

We thank the Willi Hennig Society for making TNT freely available. XW thanks National Natural Science Foundation of China (grant \#41688103, \#41790452). RVP thanks Maria E. Leal (Aarhus University) for discussions, and FAPESP for a scholarship (\#2019/10231-6). RVP and ZX deeply thank Niels Bonde (Zoological Museum, Copenhagen) for his heartful support and for fostering our network. We thank Natalia Jagielska, Steven Vidovic and an anonymous reviewer for their thorough and constructive remarks.

\section{References}

Andres, B., Clark, J. M., and Xing, X. 2010. A new rhamphorhynchid pterosaur from the Upper Jurassic of Xinjiang, China, and the phylogenetic relationships of basal pterosaurs. Journal of Vertebrate Paleontology, 30 (1), 163-187.

Andres, B., Clark, J.M. and Xu, X. 2014. The earliest pterodactyloid and the origin of the group. Current Biology, 24, 1011-1016.

Bakhurina, N. N., and Unwin, D. M. 1995. A survey of pterosaurs from the Jurassic and Cretaceous of the former Soviet Union and Mongolia. Historical Biology 10, 197-245.

Bardin, J., Rouget, I., Yacobucci, M. M., \& Cecca, F. 2014. Increasing the number of discrete character states for continuous characters generates well-resolved trees that do not reflect phylogeny. Integrative Zoology, 9(4), 531-541.

Bennett, S. C. 2007. A second specimen of the pterosaur Anurognathus ammoni. Paläontologische Zeitschrift, 81 (4), 376. 
827 Bennett, S. C. 2014. A new specimen of the pterosaur Scaphognathus crassirostris, with

828

829

830

831

832

833

834

835

836

837

838

839

840

841

842

843

844

845

846

847

848

849

850

851

852

853

comments on constraint of cervical vertebrae number in pterosaurs. Neues Jahrbuch für Geologie und Paläontologie-Abhandlungen, 271 (3), 327-348.

Britt, B. B., Dalla Vecchia, F. M., Chure, D. J., Engelmann, G. F., Whiting, M. F., and Scheetz, R. D. 2018. Caelestiventus hanseni gen. et sp. nov. extends the desert-dwelling pterosaur record back 65 million years. Nature ecology and evolution, 2 (9), 1386-1392.

Clark, J. M., Hopson, J. A., Fastovsky, D. E., and Montellano, M. 1998. Foot posture in a primitive pterosaur. Nature, 391 (6670), 886-889.

Codorniú, L., Carabajal, A. P., Pol, D., Unwin, D. M. and Rauhut, O. W. 2016. A Jurassic pterosaur from Patagonia and the origin of the pterodactyloid neurocranium. PeerJ, 4, e2311.

Colless, D.H. 1985. On "character" and related terms. Systematic Zoology, 34, 229-233.

Costa, F. R., Alifanov, V., Dalla Vecchia, F. M., Kellner, A. W. A. 2013. On the presence of an elongated tail in an undescribed specimen of Batrachognathus volans (Pterosauria: Anurognathidae: Batrachognathinae). In Sayão, J. M., Costa, F. R., Bantim, R. A. M., Kellner, A. W. A. (eds). Short communications, Rio Ptero 2013 - International Symposium on Pterosaurs. Rio de Janeiro: Universidade Federal do Rio de Janeiro, Museu Nacional, 54-56.

Chang, S. C., Zhang, H., Renne, P. R., and Fang, Y. 2009. High-precision 40Ar/39Ar age for the Jehol Biota. Palaeogeography, Palaeoclimatology, Palaeoecology, 280 (1-2), 94-104.

Cheng, X., Wang, X., Jiang, S., \& Kellner, A. W. 2012. A new scaphognathid pterosaur from western Liaoning, China. Historical Biology, 24 (1), 101-111.

Cheng X, Wang X, Jiang S, Kellner A W. 2015. Short note on a non-pterodactyloid pterosaur from Upper Jurassic deposits of Inner Mongolia, China. Historical Biology, 27 (6), 749-754.

Cheng, X., Jiang, S., Wang, X., and Kellner, A. W. 2017. New anatomical information of the wukongopterid Kunpengopterus sinensis Wang et al., 2010 based on a new specimen. PeerJ, 5, e4102.

Chu, Z., He, H., Ramezani, J., Bowring, S. A., Hu, D., Zhang, L., ... \& Guo, J. 2016. High-precision $\mathrm{U}-\mathrm{Pb}$ geochronology of the Jurassic Yanliao Biota from Jianchang (western

Peer) reviewing PDF | (2020:10:53890:2:0:NEW 25 Feb 2021) 
854

855

856

857

858

859

860

861

862

863

864

865

866

867

868

869

870

871

872

873

874

875

876

877

878

879

Liaoning Province, China): Age constraints on the rise of feathered dinosaurs and eutherian mammals. Geochemistry, Geophysics, Geosystems, 17 (10), 3983-3992.

Dalla Vecchia, F. M. 1998. New observations on the osteology and taxonomic status of Preondactylus buffarinii Wild, 1984 (Reptilia, Pterosauria). Bollettino della Societá Paleontologica Italiana, 36, 355-366.

Dalla Vecchia, F. M. 2002. Observations on the non-pterodactyloid pterosaur Jeholopterus ningchengensis from the Early Cretaceous of northeastern China. Natura Nascosta, 24, 8-27.

Dalla Vecchia, F. M. 2009. Anatomy and systematics of the pterosaur Carniadactylus gen. n. rosenfeldi (Dalla Vecchia, 1995). Rivista Italiana di Paleontologia e stratigrafia, 115 (2), $159-188$.

Dalla Vecchia, F. M. 2014. Triassic pterosaurs. Geological Society, London, Special Publications, 379 (1), 119-155.

Dalla Vecchia, F. M. 2018. Comments on Triassic pterosaurs with a commentary on the" ontogenetic stages" of Kellner (2015) and the validity of Bergamodactylus wildi. Rivista Italiana di Paleontologia e Stratigrafia, 124 (2).

Dalla Vecchia, F. M. 2019. Seazzadactylus venieri gen. et sp. nov., a new pterosaur (Diapsida: Pterosauria) from the Upper Triassic (Norian) of northeastern Italy. PeerJ, 7, e7363.

Dalla Vecchia, F. M., Wild, R., Hopf, H., and Reitner, J. 2002. A crested rhamphorhynchoid pterosaur from the Late Triassic of Austria. Journal of Vertebrate Paleontology, 22 (1), 196199.

Döderlein, L. 1923. Anurognathus ammoni ein neuer Flugsaurier. Sitzungsberichte der Bayerischen Akademie der Wissenschaften, Mathematisch-Naturwissenschaftlichen, 1923, 117-164 Elgin, R. A., Hone, D. W., \& Frey, E. 2011. The extent of the pterosaur flight membrane. Acta Palaeontologica Polonica, 56(1), 99-111.

Fitzhugh, K. 2006. The philosophical basis of character coding for the inference of phylogenetic hypotheses. Zoologica scripta, 35(3), 261-286. 
880 Gao, K. Q., and Shubin, N. H. 2012. Late Jurassic salamandroid from western Liaoning, 881 China. Proceedings of the National Academy of Sciences, 109 (15), 5767-5772.

882 Gao, K. Q., Li, Q., Wei, M., Pak, H., and Pak, I. 2009. Early Cretaceous birds and pterosaurs 883 from the Sinuiju Series, and geographic extension of the Jehol Biota into the Korean

885 886

887

888

889

890

891

892

893

894

895

896

897

898

899

900

901

902

903

904 Peninsula. J Paleontol Soc Korea, 25 (1), 57-61.

Goloboff, P. A., Farris, J. S., and Nixon, K. C. 2008. TNT, a free program for phylogenetic analysis. Cladistics, 24 (5), 774-786.

Habib, M. B. 2011. Functional morphology of anurognathid pterosaurs. In Geological Society of America Abstracts with Programs 43 (1), 118.

Holgado, B., Pêgas, R. V., Canudo, J. I., Fortuny, J., Rodrigues, T., Company, J., and Kellner, A. W. 2019. On a new crested pterodactyloid from the Early Cretaceous of the Iberian Peninsula and the radiation of the clade Anhangueria. Scientific reports, 9 (1), 1-10.

Hone, D. W. 2020. A review of the taxonomy and palaeoecology of the Anurognathidae (Reptilia, Pterosauria). Acta Geologica Sinica-English Edition. In press.

Huang D. 2015. Yangliao biota and Yanshan movement (in Chinese). Acta Palaeontologica Sinica, 54, 501-546.

Huang D. 2016. The Daohugou Biota (in Chinese). Shanghai: Shanghai Scientific \& Technical Publishers. 332 pp.

Huang D. 2019. Jurassic integrative stratigraphy and timescale of China. Science China Earth Sciences, 62, 223-255.

Jensen, J. A., and Padian, K. 1989. Small pterosaurs and dinosaurs from the Uncompahgre fauna (Brushy Basin member, Morrison formation:? Tithonian), late Jurassic, western Colorado. Journal of Paleontology, 364-373.

Ji, S. and Ji, Q. 1998. Discovery of a new pterosaur in Western Liaoning, China. Acta Geologica Sinica 71, 115. 
905 906

907

908

909

910

911

912

913

914

915

916

917

918

919

920

921

922

923

924

925

926

927

928

929

930

931

932

Ji, Q., and Yuan, C. X. 2002. Discovery of two kinds of protofeathered pterosaurs in the Mesozoic Daohugou Biota in the Ningcheng region and its stratigraphic and biologic significances. Geological Review, 48 (2), 221-224.

Jiang, S., Wang, X., Cheng, X., Costa, F. R., Huang, J., and Kellner, A. W. 2014. Short note on an anurognathid pterosaur with a long tail from the Upper Jurassic of China. Historical Biology, 27 (6), 718-722.

Kellner, A. W. A. 2003. Pterosaur phylogeny and comments on the evolutionary history of the group. Geological Society, London, Special Publications, 217, 105-137.

Kellner, A. W., Wang, X., Tischlinger, H., Campos, D. A., Hone, D. W., and Meng, X. 2010. The soft tissue of Jeholopterus (Pterosauria, Anurognathidae, Batrachognathinae) and the structure of the pterosaur wing membrane. Proceedings of the Royal Society B: Biological Sciences, 277 (1679), 321-329.

Kuhn, O. 1967. Die fossile Wirbeltierklasse Pterosauria. Krailing bei München, Oeben.

Li B., Cheng J., Liu M., Yang F., Wu Z., Du J. 2019. Formation age and geochemical characteristics of the Tiaojishan Formation in the Western Liaoning Province (in Chinese). Geological Review, 65, 63-64.

Liu, Y., Liu, Y., and Yang, Z. 2006. U-Pb zircon age for the Daohugou Biota at Ningcheng of Inner Mongolia and comments on related issues. Chinese Science Bulletin, 51 (21), 26342644

Liu Y., Kuang H., Jiang X., Peng N., Xu H., Sun H. 2012. Timing of the earliest known feathered dinosaurs and transitional pterosaurs older than the Jehol Biota. Palaeogeography, Palaeoclimatology, Palaeoecology, 323, 1-12.

Longrich, N. R., Martill, D. M., and Andres, B. 2018. Late Maastrichtian pterosaurs from North Africa and mass extinction of Pterosauria at the Cretaceous-Paleogene boundary. PLoS biology, 16 (3), e2001663.

Lü, J. 2009. A new non-pterodactyloid pterosaur from Qinglong County, Hebei Province of China. Acta Geologica Sinica-English Edition, 83 (2), 189-199. 
933 Lü, J., and Bo, X. 2011. A new rhamphorhynchid pterosaur (Pterosauria) from the Middle 934 Jurassic Tiaojishan Formation of western Liaoning, China. Acta Geologica Sinica-English 935 Edition, 85 (5), 977-983.

936 Lü, J., and Hone, D. W. 2012. A new Chinese anurognathid pterosaur and the evolution of 937 pterosaurian tail lengths. Acta Geologica Sinica-English Edition, 86 (6), 1317-1325.

938 Lü, J., Fucha, X. H., and Chen, J. M. 2010. A new scaphognathine pterosaur from the Middle 939 Jurassic of western Liaoning, China. Diqiu Xuebao(Acta Geoscientica Sinica), 31 (2), 263940266.

941 Lü J, Jin X, Gao C, Du T, Ding M, Sheng Y, Wei X. 2013. Dragons of the Skies (recent 942 advances on the study of pterosaurs from China) (in Chinese). Zhejiang Science \& 943 Technology Press, 127.

944

945

946

947

948

949

950

951

952

953

954

955

956

957

958

959

960

Lü J., Meng Q., Wang B., Liu D., Shen C., and Zhang Y. 2018. Short note on a new anurognathid pterosaur with evidence of perching behaviour from Jianchang of Liaoning Province, China. Geological Society, London, Special Publications, 455, 95-104.

Lü J., Unwin D.M., Jin X.S., Liu Y.Q., and Ji Q. 2009. Evidence for modular evolution in a long-tailed pterosaur with a pterodactyloid skull. Proceedings of the Royal Society B: Biological Sciences 277(1680), 383-389.

Lü, J., Unwin, D.M., Zhao, B., Gao, C., \& Shen, C. 2012. A new rhamphorhynchid (Pterosauria: Rhamphorhynchidae) from the Middle/Upper Jurassic of Qinglong, Hebei Province, China. Zootaxa, 3158(1), 1-19.

Mongiardino Koch, N., Soto, I. M., \& Ramírez, M. J. 2015. Overcoming problems with the use of ratios as continuous characters for phylogenetic analyses. Zoologica Scripta, 44(5), 463-474.

Naish, D., Simpson, M., \& Dyke, G. 2013. A new small-bodied azhdarchoid pterosaur from the Lower Cretaceous of England and its implications for pterosaur anatomy, diversity and phylogeny. PloS one, 8(3), e58451.Padian, K. 1983. Osteology and functional morphology of Dimorphodon macronyx (Buckland) (Pterosauria: Rhamphorhynchoidea) based on new material in the Yale Peabody Museum. Postilla, 189, 1-44. 
961 Padian, K. 2008a. The Toarcian (Early Jurassic) pterosaur Dorygnathus

962 Wagner, 1860. Palaeontology, 80, 1-64.

963 Padian, K. 2008b. The Early Jurassic pterosaur Campylognathoides Strand, 964 1928. Palaeontology 80, 65-107.

965

966

967

968

969

970

971

972

973

974

975

976

977

978

979

980

981

982

983

984

985

986

987

Pêgas, R. V., Holgado, B. and Leal, M. E. C. 2019. On Targaryendraco wiedenrothi gen. nov. (Pterodactyloidea, Pteranodontoidea, Lanceodontia) and recognition of a new cosmopolitan lineage of Cretaceous toothed pterodactyloids. Historical Biology, 2019, 1-15.

Riabinin, A. N. 1948. Remarks on a flying reptile from the Jurassic of Kara-Tau. [In Russian.] Akademii Nauk, Paleontological Institute, Trudy 15, 86-93.

Sullivan C., Wang Y., Hone D.W.E., Wang Y.Q., Xu X., Zhang F.C. 2014. The vertebrates of the Jurassic Daohugou Biota of northeastern China. Journal of Vertebrate Paleontology, 34(2), 243-280.

Thiele, K. 1993. The Holy Grail of the perfect character: the cladistic treatment of morphometric data. Cladistics, 9, 275-304.

Unwin, D. M., \& Bakhurina, N. N. 1994. Sordes pilosus and the nature of the pterosaur flight apparatus. Nature, 371(6492), 62-64.

Unwin, D. M., Lü, J., and Bakhurina, N. N. 2000. On the systematic and stratigraphic significance of pterosaurs from the Lower Cretaceous Yixian Formation (Jehol Group) of Liaoning, China. Fossil Record, 3(1), 181-206.

Unwin, D. M. 1992. The phylogeny of the Pterosauria. Journal of Vertebrate Paleontology, 12(3), 57A.

Unwin, D. M. 1995. Preliminary results of a phylogenetic analysis of the Pterosauria (Diapsida: Archosauria)', in Sixth Symposium on Mesozoic Terrestrial Ecosystems and Biota. China Ocean Press Beijing, China, pp. 69-72.

Unwin, D. M. 2003. On the phylogeny and evolutionary history of pterosaurs. Geological Society, London, Special Publications, 217, 139-190. 
988 Vidovic, S. U. 2018. Transformation of Quotient Values for their use as Continuous Cladistic $989 \quad$ Characters. bioRxiv, 333781.

990

991

992

993

994

995

996

997

998

999

1000

1001

1002

1003

1004

1005

1006

1007

1008

1009

1010

1011

1012

1013

1014

1015

Vidovic, S. U. and Martill, D. M. 2017. The taxonomy and phylogeny of Diopecephalus kochi (Wagner, 1837) and 'Germanodactylus rhamphastinus' (Wagner, 1851). Geological Society, London, Special Publications, 455(1), 125-147.

Viscardi, P., Dyke, G.J., Wilkinson, M., and Rayner, J.M.V. 1999. Missing data and the phylogeny of the Pterosauria. Journal of Vertebrate Paleontology, 19, 82A.

Wang, X., Zhou, Z., Zhang, F., and Xu, X. 2002. A nearly completely articulated rhamphorhynchoid pterosaur with exceptionally well-preserved wing membranes and "hairs" from Inner Mongolia, northeast China. Chinese Science Bulletin, 47(3), 226-230.

Wang, X., Kellner, A. W., Zhou, Z., and De Almeida Campos, D. 2005. Pterosaur diversity and faunal turnover in Cretaceous terrestrial ecosystems in China. Nature, 437(7060), 875879.

Wang, X., Kellner, A. W., Jiang, S., and Meng, X. 2009. An unusual long-tailed pterosaur with elongated neck from western Liaoning of China. Anais da Academia Brasileira de Ciências, 81(4), 793-812.

Wang, X., Kellner, A. W., Jiang, S., Cheng, X., Meng, X., and Rodrigues, T. 2010. New long-tailed pterosaurs (Wukongopteridae) from western Liaoning, China. Anais da Academia Brasileira de Ciências, 82(4), 1045-1062.

Wang, X., Kellner, A. W., Jiang, S., and Cheng, X. 2012. New toothed flying reptile from Asia: close similarities between early Cretaceous pterosaur faunas from China and Brazil. Naturwissenschaften, 99(4), 249-257.

Wellnhofer, P. 1970. Die Pterodactyloidea (Pterosauria) der OberjuraPlattenkalke Süddeutschlands. Bayerische Akademie der Wissenschaften, MathematischWissenschaftlichen Klasse, Abhandlungen 141, 1-133.

Wellnhofer, P. 1975. Die Rhamphorhynchoidea (Pterosauria) der Oberjura-Plattenkalke Suddeutschlands. Palaeontogr. A., 148, 1-33. Wellnhofer, P. 1978. Pterosauria. Handbuch der Palaeoherpetologie, Teil 19. Stuttgart: Gustav Fischer Verlag. 
1016 Wellnhofer, P. 1991. The Illustrated Encyclopaedia of Pterosaurs. London, Salamander Books.

1017 Witton, M. P. 2008. A new approach to determining pterosaur body mass and its implications 1018 for pterosaur flight. Zitteliana, 143-158.

1019 Witton, M. P. 2013. Pterosaurs: natural history, evolution, anatomy. Princeton University Press.

1020

1021

1022

1023

1024

1025

1026

1027

1028

1029

1030

1031

1032

1033

1034

1035

1036

1037

1038

1039

1040

1041

Wu, W. H., Zhou, C. F. and Andres, B. 2017. The toothless pterosaur Jidapterus edentus (Pterodactyloidea: Azhdarchoidea) from the Early Cretaceous Jehol Biota and its paleoecological implications. PloS One, 12, e0185486.

Yang, Z., Jiang, B., Mcnamara, M. E., Kearns, S. L., Pittman, M., Kaye, T. G., ... and Benton, M. J. 2019. Pterosaur integumentary structures with complex feather-like branching. Nature ecology and evolution, 3(1), 24-30.

Young, C. C. 1964. On a new pterosaurian from Sinkiang, China. Vertebrate Palasiatica 8, 221-225.

Zhang H., Wang M. X., Liu X. M. 2008. The upper age limit of Tiaojishan Formation (western Liaoning and northern Hebei area) volcanic rocks by LA-ICP-MS (in Chinese). Chinese Science Bulletin, 15, 1815-1824.

Zhang Y. Q., Chen H. Y. 2015. Study on the characteristics of Tiaojishan Formation (Middle Jurassic) laminar volcanic structure of Chengde Basin (in Chinese). Hebei Geology, 4, 8-10.

\section{Figures}

Figure 1. Fossil provenance. Maps indicating Hebei Province (China). JPM-2012-001 comes from the Mutoudeng locality.

Figure 2. Sinomacrops bondei tax. nov., holotype (JPM-2012-001) overview. A, photograph; and B, schematic drawing. Abbreviations: ca, caudal vertebrae; co, coracoid; cv, cervical vertebrae; d, dentary; fe, femur; fi, fibula; hu, humerus; mcIV, metacarpal IV; mt, metatarsal; pip, puboischiadic plate; prap, preacetabular process of the illium; rd, radius; sca, scapula; sk, skull; ti, tibia; ul, ulna; wp, wing phalanx. Scale bar equals $20 \mathrm{~mm}$.

Peer) reviewing PDF | (2020:10:53890:2:0:NEW 25 Feb 2021) 
1042 Figure 3. Sinomacrops bondei tax. nov., skull of JPM-2012-001. A, photograph; and B, 1043 schematic drawing. Light grey represents bones; dark grey represents soft tissue. Abbreviations: 1044 apf, anterior process of the frontal; cv, cervical vertebrae; d, dentary; f, frontal; j, jugal; la, 1045 lacrimal; na, nasal; pa, parietal; po, postorbital; pm, premaxilla; op, opisthotic; scr, sclerotic ring; $1046 \mathrm{t}$, tooth. Scale bar equals $10 \mathrm{~mm}$.

1047 Figure 4. Computed-tomography images of the wings of JPM-2012-001. A, right wing; B, 1048 left wing. Abbreviations: d, digit; dc, deltopectoral crest; hu.ep, humeral epiphysis; mc, 1049 metacarpal; ph, phalanx; rd, radius; ul, ulna.

1050

1051

1052

1053

1054

1055

1056

1057

1058

1059

1060

1061

1062

1063

1064

1065

1066

1067

1068

Figure 5. Sacral region of JPM-2012-001. A, photograph; B, schematic drawing.

Abbreviations: ac, acetabulum; ca, caudal vertebrae; fe, femur; pip, puboischiadic plate; prap, preacetabular process of the illium; sa, sacral vertebrae; sr, sacral rib. Scale bar equals $10 \mathrm{~mm}$.

Figure 6. Right pes of JPM-2012-001. Abbreviations: mt, metatarsal. Scale bar equals $10 \mathrm{~mm}$.

Figure 7. Phylogenetic analysis results. Strict consensus tree showing the phylogenetic relationships of Sinomacrops bondei and anurognathids.

Figure 8. Variation in the arching of the hemimandible in anurognathids. Schematic drawings of anurognathid hemimandibles in ventral view. A, Batrachognathus volans (based on Riabinin 1948). B, Sinomacrops bondei. C, Jeholopterus ningchengensis (based on Yang et al. 2018). D, Vesperopterylus lamadongensis (based on Lü et al. 2018). Not to scale, adjusted to matching sizes. The blue line connects the centroid and the posterior point of the hemimandible. The long red line connects the posterior and anterior points. The angle between these lines is higher in Jeholopterus and Vesperopterylus, corresponding to a higher arching degree of the jaws compared to Batrachognathus and Sinomacrops.

Figure 9. Variation in anurognathid jaw shape. Schematic drawings of anurognathid mandibles in ventral view. A, Batrachognathus volans (based on Riabinin 1948). B, Sinomacrops bondei. C, Jeholopterus ningchengensis (based on Yang et al. 2018). D, Vesperopterylus lamadongensis (based on Lü et al. 2018). Not to scale, adjusted to matching sizes. 
1069 Figure 10. Schematic drawings of anurognathid humeri. A, Batrachognathus volans (based 1070 on Riabinin 1948). B, Sinomacrops bondei. C, Dendrorhynchoides curvidentatus (based on Ji \& 1071 Ji 1999). D, Jeholopterus ningchengensis (based on Kellner et al. 2009). E, Vesperopterylus 1072 lamadongensis (based on Lü et al. 2018). F, Anurognathus ammoni based on Wellnhofer (1991). 1073 Not to scale, adjusted to matching sizes. Abbreviations: dc, deltopectoral crest; uc, ulnar crest.

1074 Figure 11. Previous phylogenetic hypotheses for the position of the Anurognathidae. 1075 Simplified cladograms. A, from Kellner (2003). B, from Unwin (2003). C, from Dalla Vecchia 1076 (2019). D, from Andres et al. (2010, 2014). E, from Vidovic \& Martill (2018). Red arrows 1077 indicate the Anurognathidae.

1078 Figure 12. Metatarsus in anurognathids. A, Vesperopterylus lamadongensis holotype 1079 BMNHC-PH-001311. B, schematic drawing. C, Jeholopterus ningchengensis specimen CAGS 1080 IG 02-81. D, schematic drawing. Numbers refer to metatarsals. Scale bar equals $10 \mathrm{~mm}$.

1081

1082

1083

1084

1085

1086

1087

1088

1089

1090

1091

1092

1093

1094

1095
Figure 13. Nasoantorbital fenestra in Jeholopterus CAGS IG 02-81. A, skull exposed in dorsal view, and B, schematic drawing. Abbreviations: fr, frontal; j, jugal; mand, mandible; naof, nasoantorbital fenestra; or, orbit; pa, parietal; pal, palatine; pm, premaxilla. Scale bar equals 10 $\mathrm{mm}$.

Figure 14. Life reconstruction of Sinomacrops bondei. Paleoart courtesy of Zhao Chuang, reproduced with permission.

\section{Tables}

Table 1. Measurements of JPM-2012-001. Measurements are given in centimeters. Values for long bones correspond to their lengths. Interrogations mean the element is too incomplete for an informative value. Dashes mean the element is not preserved. Asterisk means the element is slightly incomplete.

Table 2. Comparative table showing skeletal element ratios among anurognathids.

\section{Supplemental Files}


1096 Supplemental Table S1. Morphometric dataset. Morphometric values that were subjected to 1097 gap-weighting for character coding.

1098 Supplemental File 1. Mesquite file. A nexus-format file for Mesquite, containing the 1099 phylogenetic data matrix.

1100 Supplemental File 2. TNT file for the phylogenetic analysis. 
Figure 1

Figure 1. Fossil provenance.

Maps indicating Hebei Province (China). JPM-2012-001 comes from the Mutoudeng locality.

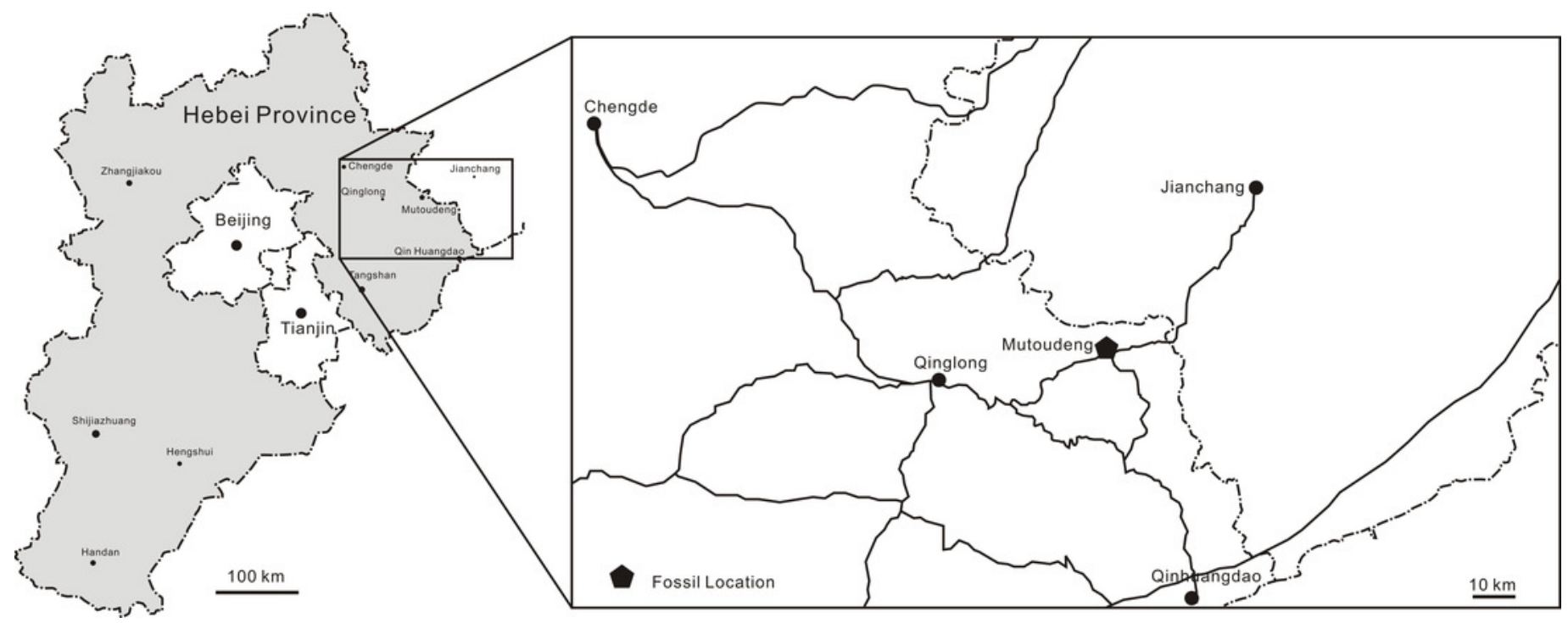




\section{Figure 2}

Figure 2. Sinomacrops bondei tax. nov., holotype (JPM-2012-001) overview.

A, photograph; and B, schematic drawing. Abbreviations: ca, caudal vertebrae; co, coracoid; cv, cervical vertebrae; d, dentary; fe, femur; fi, fibula; hu, humerus; mcIV, metacarpal IV; pip, puboischiadic plate; prap, preacetabular process of the illium; rd, radius; sca, scapula; sk, skull; ul, ulna; wp, wing phalanx. Scale bar equals $20 \mathrm{~mm}$.
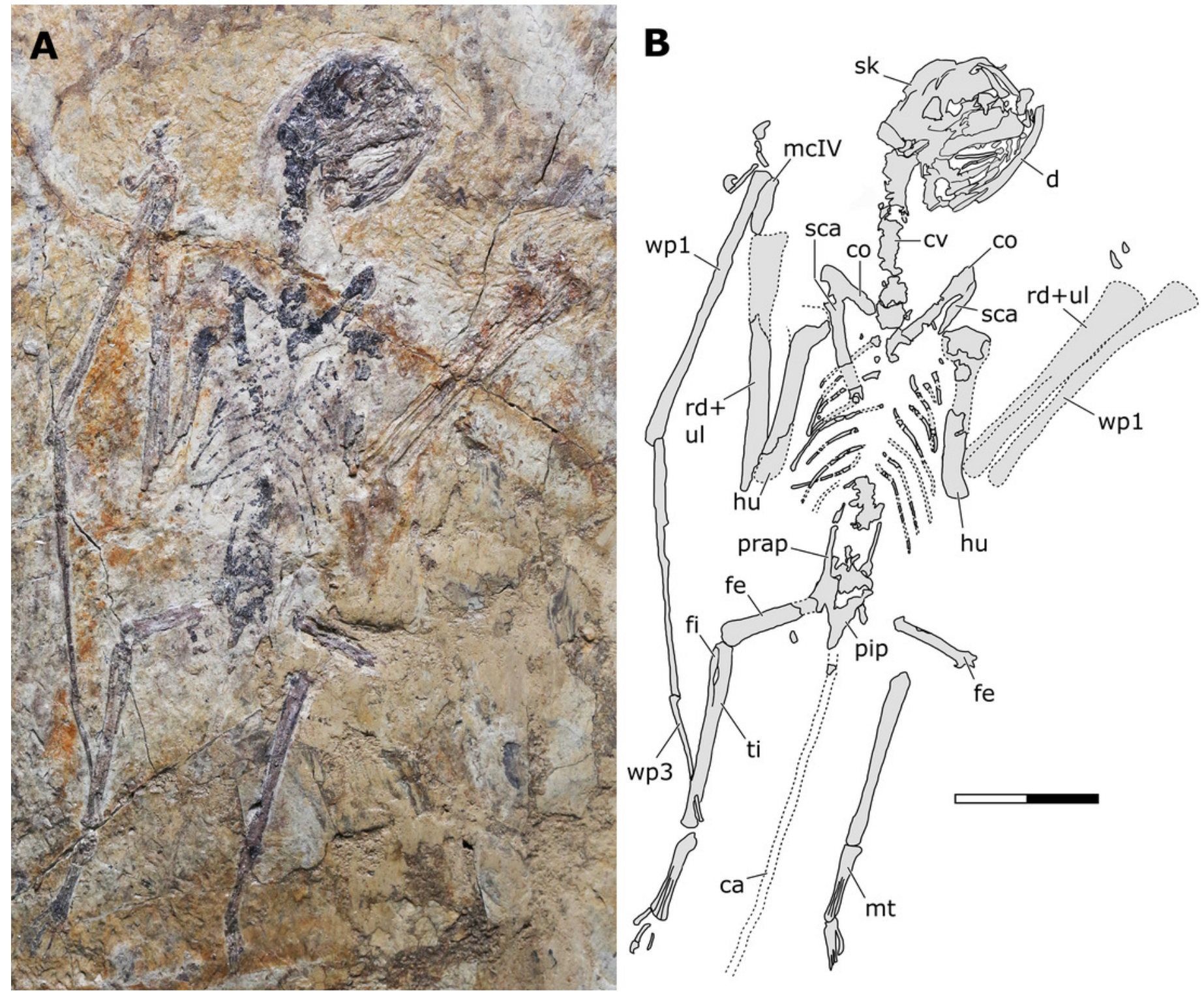


\section{Figure 3}

Figure 3. Sinomacrops bondei tax. nov., skull of JPM-2012-001.

A, photograph; and B, schematic drawing. Light grey represents bones; dark grey represents soft tissue. Abbreviations: apf, anterior process of the frontal; cv, cervical vertebrae; $d$, dentary; f, frontal; j, jugal; la, lacrimal; na, nasal; pa, parietal; po, postorbital; pm, premaxilla; op, opisthotic; scr, sclerotic ring. Scale bar equals $10 \mathrm{~mm}$.
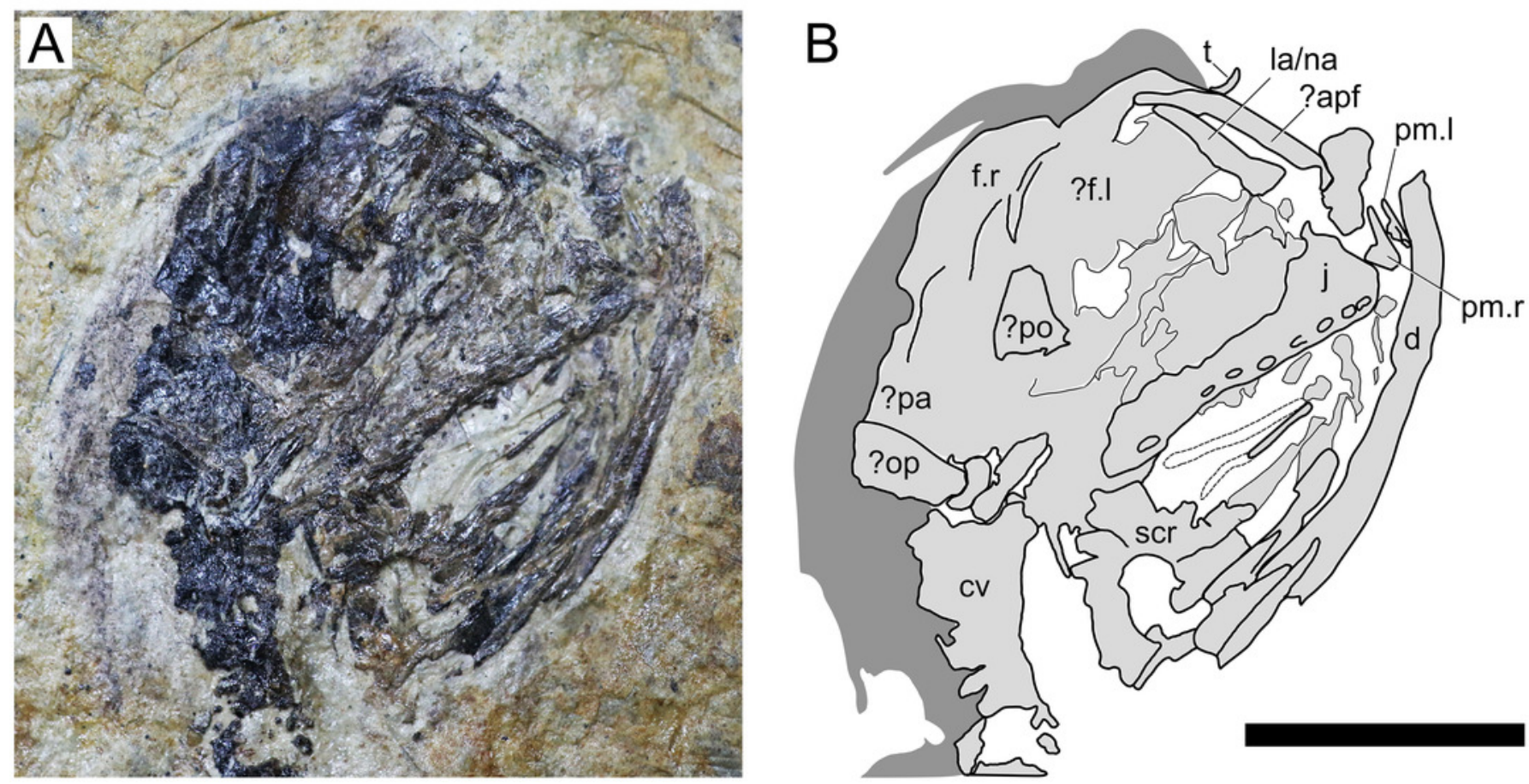


\section{Figure 4}

Figure 4. Computed-tomography images of the wings of JPM-2012-001.

A, right wing; $B$, left wing. Abbreviations: d, digit; dc, deltopectoral crest; hu.ep, humeral epiphysis; mc, metacarpal; ph, phalanx; rd, radius; ul, ulna.
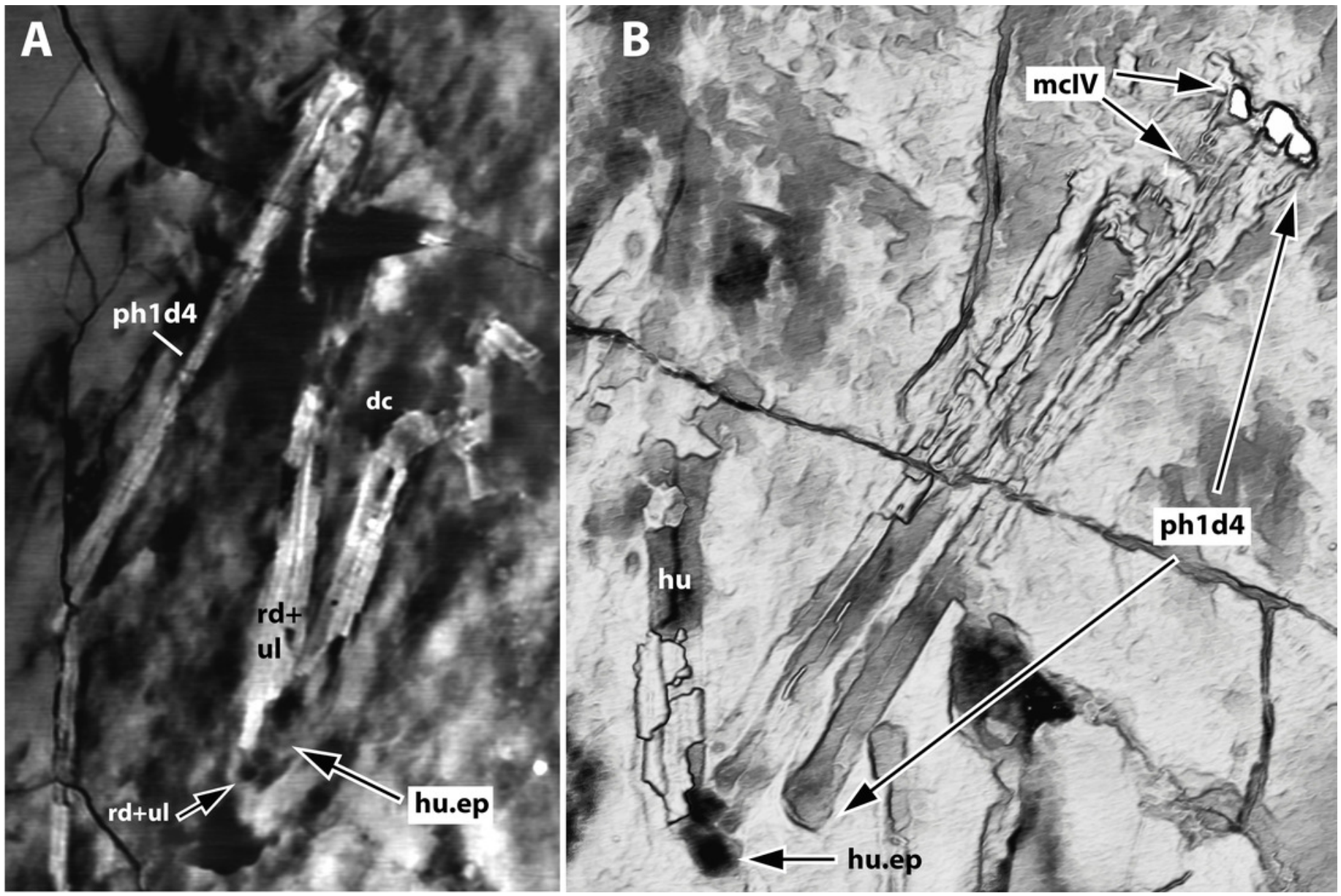
Figure 5

Figure 5. Sacral region of JPM-2012-001.

A, photograph; B, schematic drawing. Abbreviations: ac, acetabulum; ca, caudal vertebrae; fe, femur; pip, puboischiadic plate; prap, preacetabular process of the illium; sa, sacral vertebrae; sr, sacral rib. Scale bar equals $10 \mathrm{~mm}$.
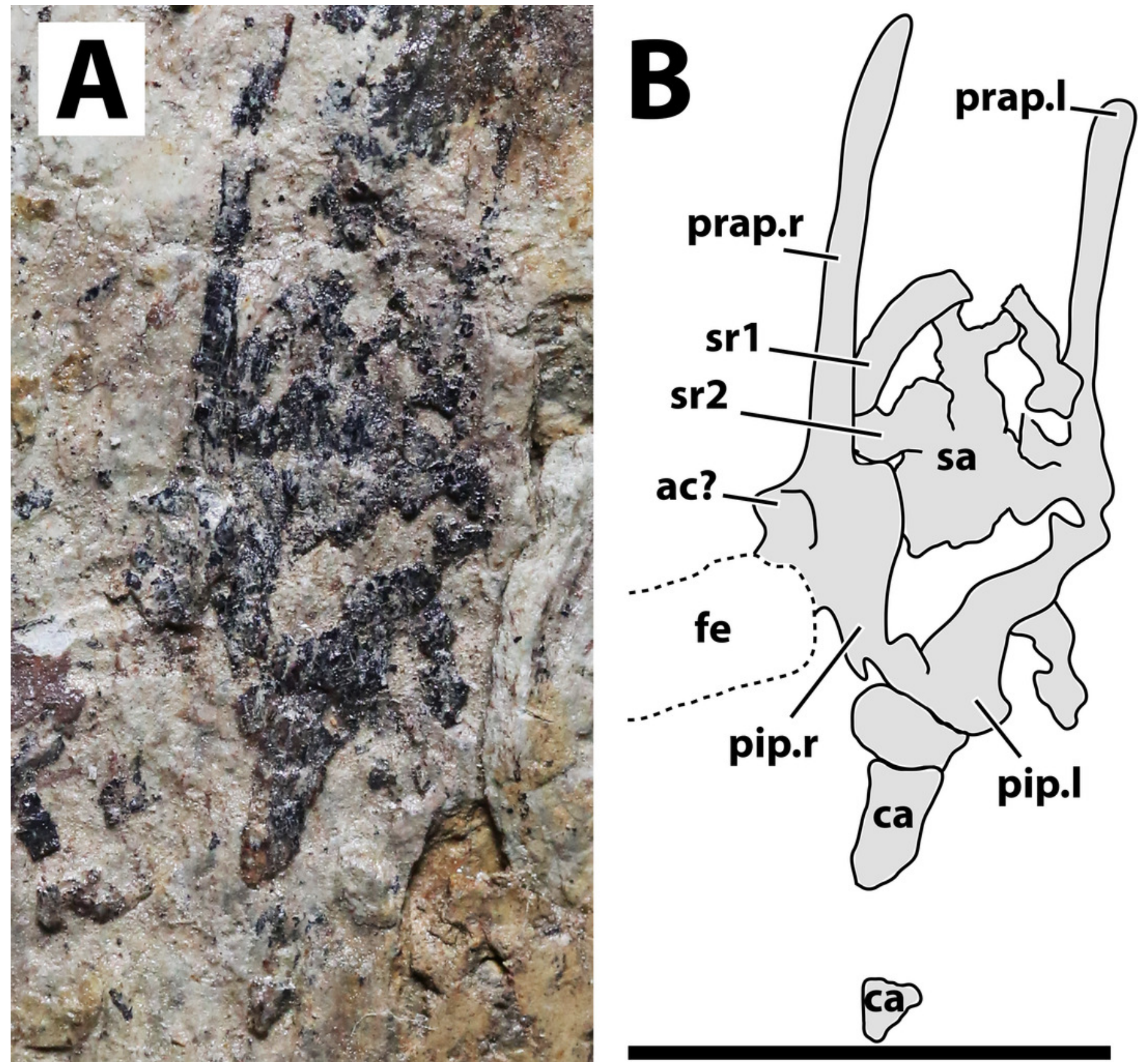
Figure 6

Figure 6. Right pes of JPM-2012-001.

Abbreviations: $\mathrm{mt}$, metatarsal. Scale bar equals $10 \mathrm{~mm}$. 





Figure 7

Figure 7. Phylogenetic analysis results.

Strict consensus tree showing the phylogenetic relationships of Sinomacrops bondei and anurognathids. Dashed line indicates result exclusive to the semi-strict consensus tree.

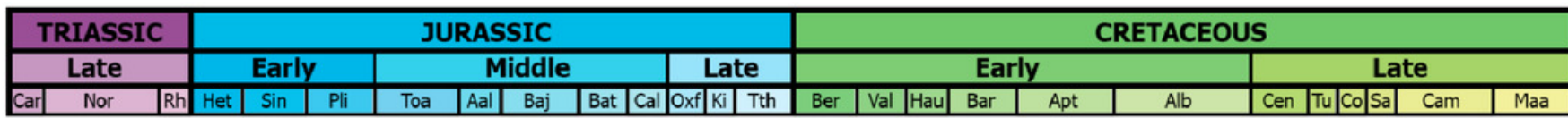

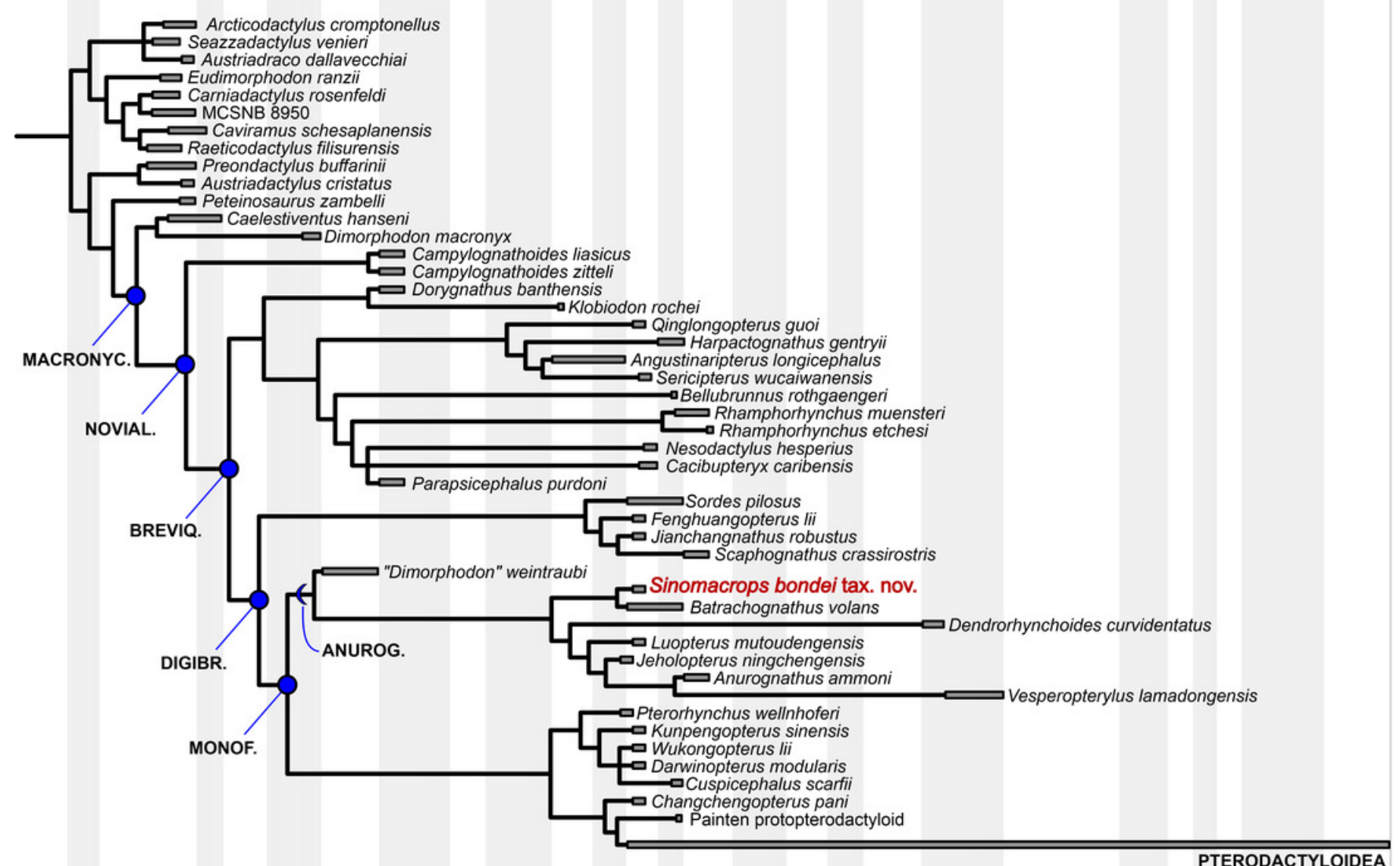




\section{Figure 8}

Figure 8. Variation in the arching of the hemimandible in anurognathids.

Schematic drawings of anurognathid hemimandibles in ventral view. A, Batrachognathus volans (based on Riabinin 1948). B, Sinomacrops bondei. C, Jeholopterus ningchengensis (based on Yang et al. 2018). D, Vesperopterylus lamadongensis (based on Lü et al. 2018). Not to scale, adjusted to matching sizes. The blue line connects the centroid and the posterior point of the hemimandible. The long red line connects the posterior and anterior points. The angle between these lines is higher in Jeholopterus and Vesperopterylus, corresponding to a higher arching degree of the jaws compared to Batrachognathus and Sinomacrops. 


Figure 9

Figure 9. Variation in anurognathid jaw shape.

Schematic drawings of anurognathid mandibles in ventral view. A, Batrachognathus volans (based on Riabinin 1948). B, Sinomacrops bondei. C, Jeholopterus ningchengensis (based on Yang et al. 2018). D, Vesperopterylus lamadongensis (based on Lü et al. 2018). Not to scale, adjusted to matching sizes.
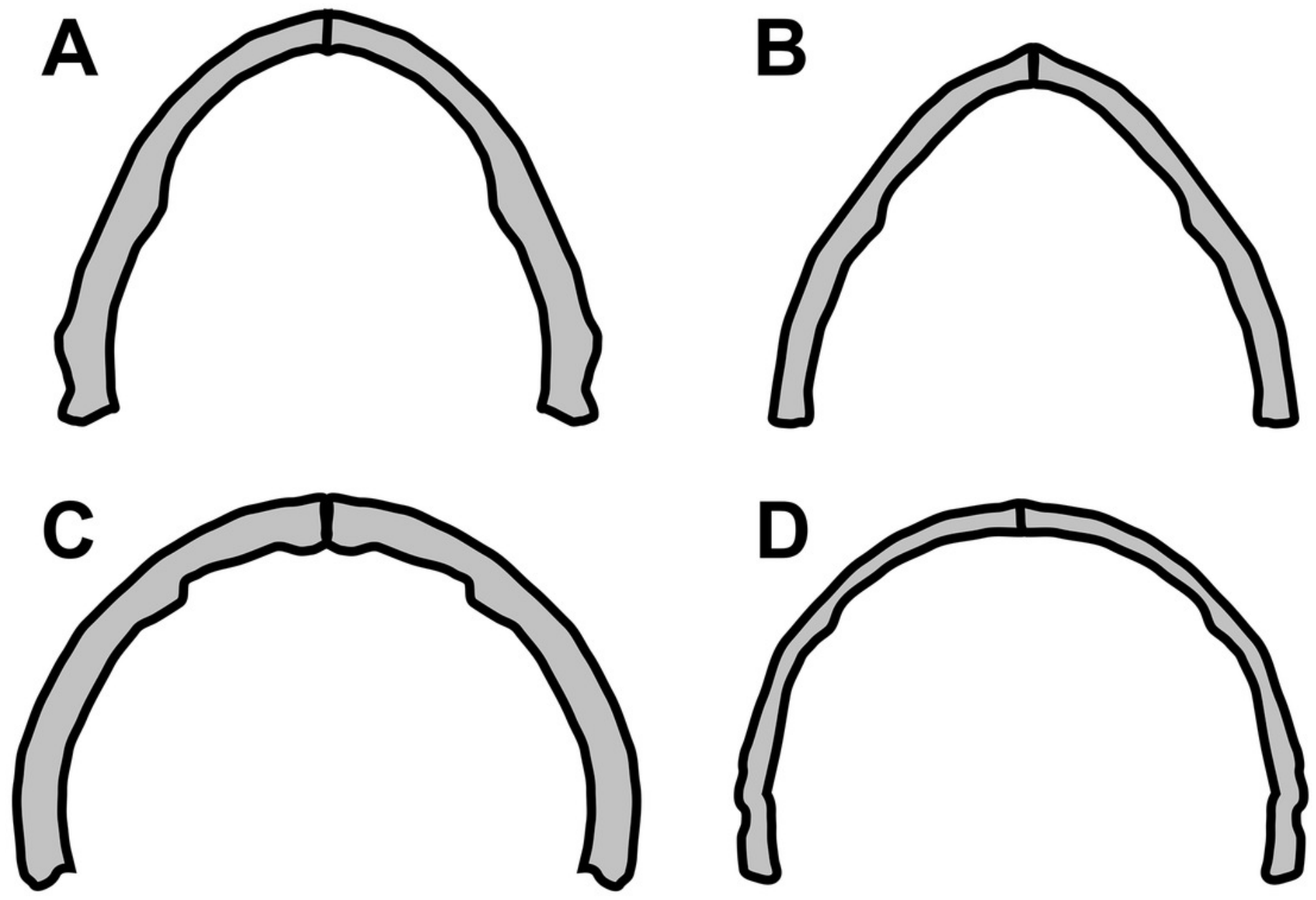


\section{Figure 10}

Figure 10. Schematic drawings of anurognathid humeri.

A, Batrachognathus volans (based on Riabinin 1948). B, Sinomacrops bondei. C, Dendrorhynchoides curvidentatus (based on Ji \& Ji 1999). D, Jeholopterus ningchengensis (based on Kellner et al. 2009). E, Vesperopterylus lamadongensis (based on Lü et al. 2018). F, Anurognathus ammoni based on Wellnhofer (1991). Not to scale, adjusted to matching sizes. Abbreviations: dc, deltopectoral crest; uc, ulnar crest. 

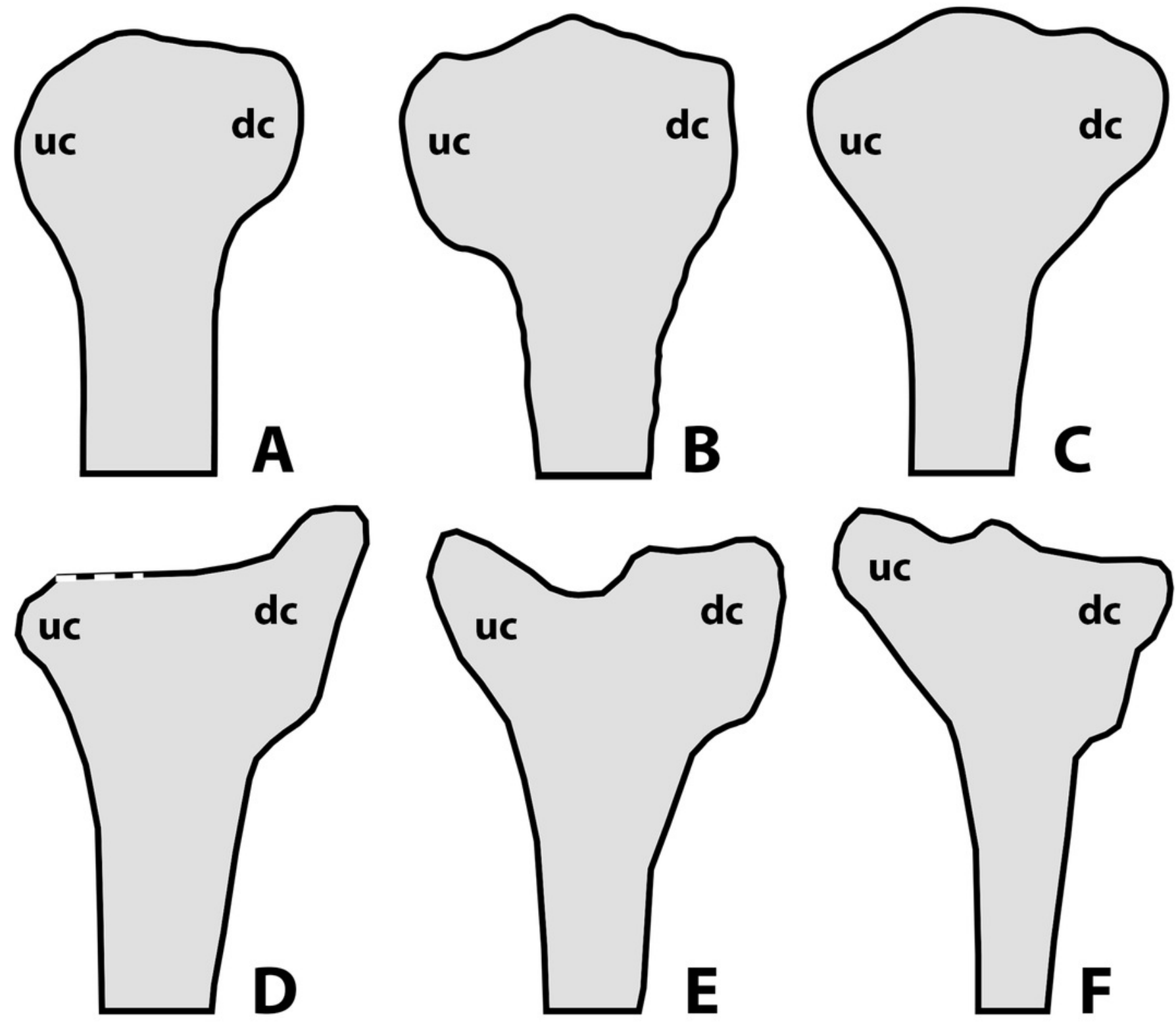
Figure 11

Figure 11. Previous phylogenetic hypotheses for the position of the Anurognathidae.

Simplified cladograms. A, from Kellner (2003). B, from Unwin (2003). C, from Dalla Vecchia (2019). D, from Andres et al. (2010, 2014). E, from Vidovic \& Martill (2018). Red arrows

indicate the Anurognathidae.
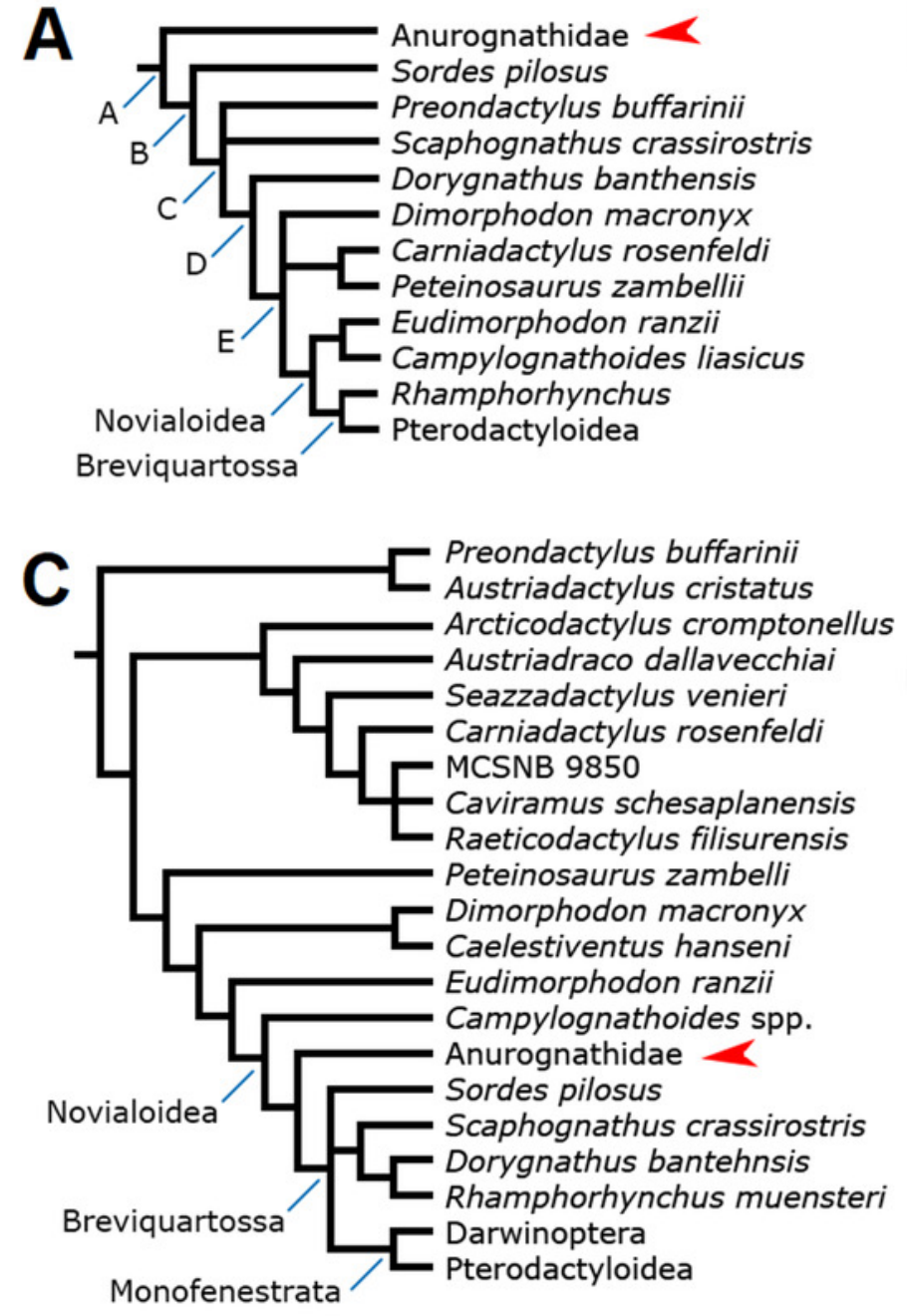
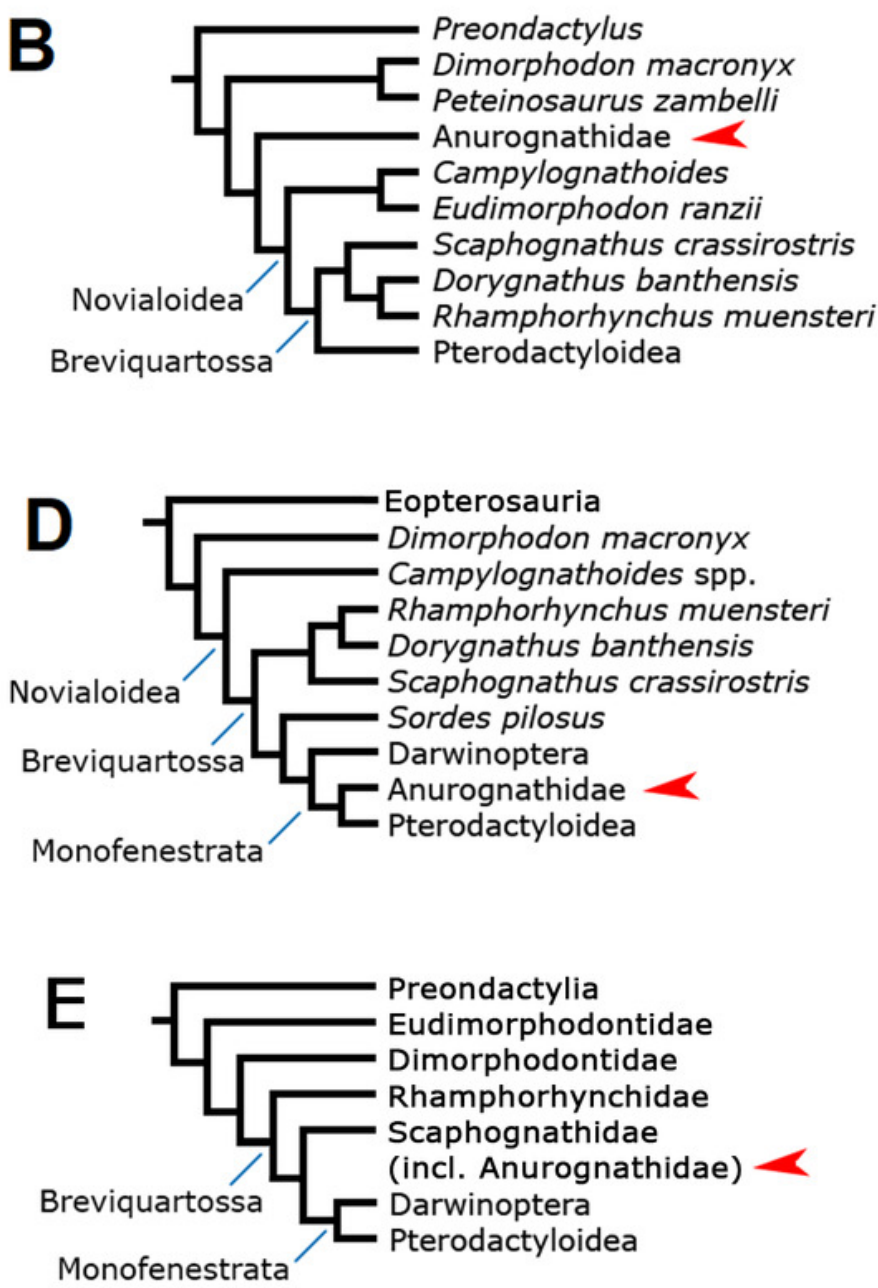


\section{Figure 12}

Figure 12. Metatarsus in anurognathids.

A, Vesperopterylus lamadongensis holotype BMNHC-PH-001311. B, schematic drawing. C, Jeholopterus ningchengensis specimen CAGS IG 02-81. D, schematic drawing. Numbers refer to metatarsals. Scale bar equals $10 \mathrm{~mm}$.
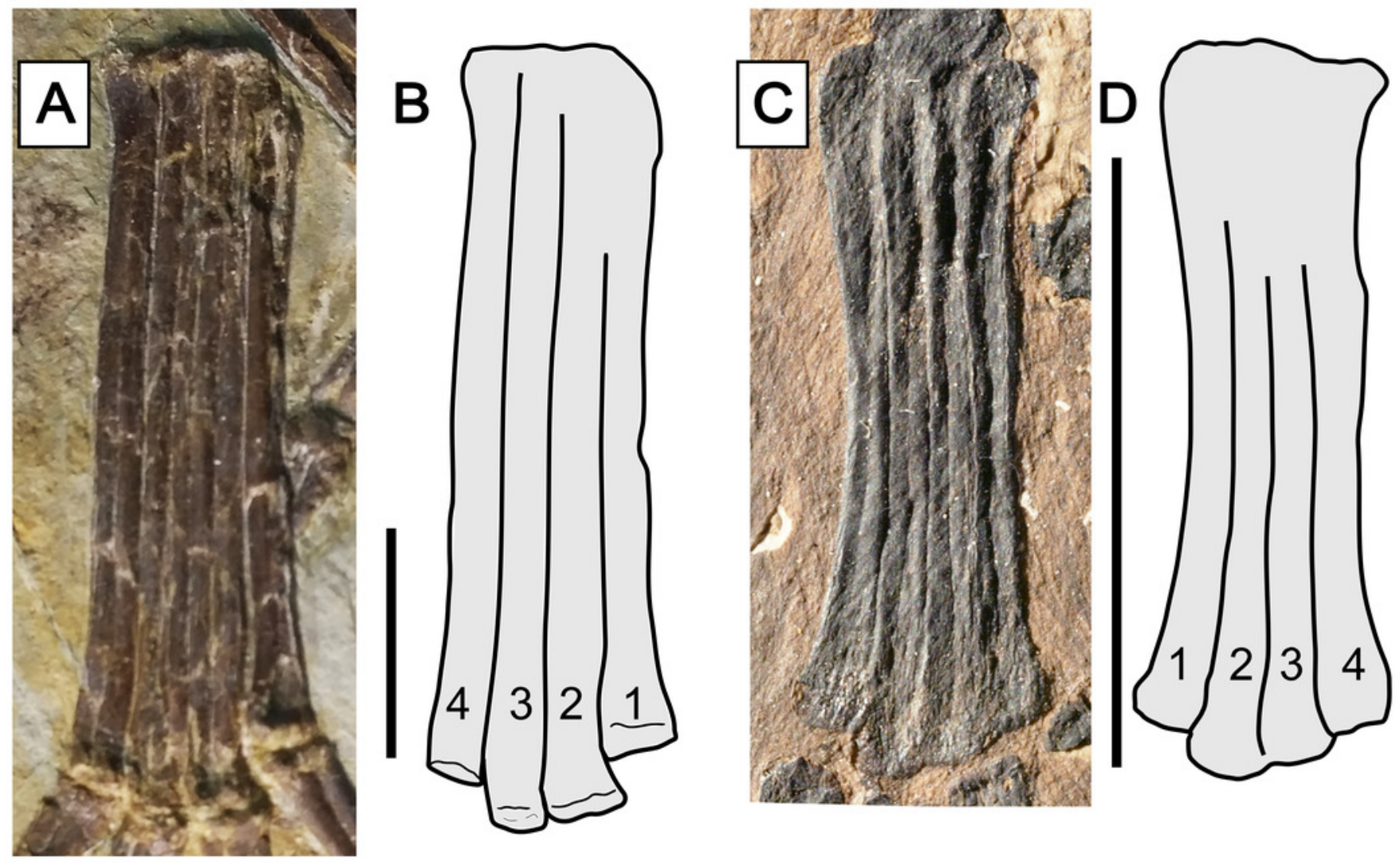


\section{Figure 13}

Figure 13. Nasoantorbital fenestra in Jeholopterus CAGS IG 02-81.

A, skull exposed in dorsal view, and B, schematic drawing. Abbreviations: fr, frontal; mand, mandible; max, maxilla; naof, nasoantorbital fenestra; or, orbit; pa, parietal; pal, palatine; pm, premaxilla. Scale bar equals $10 \mathrm{~mm}$.

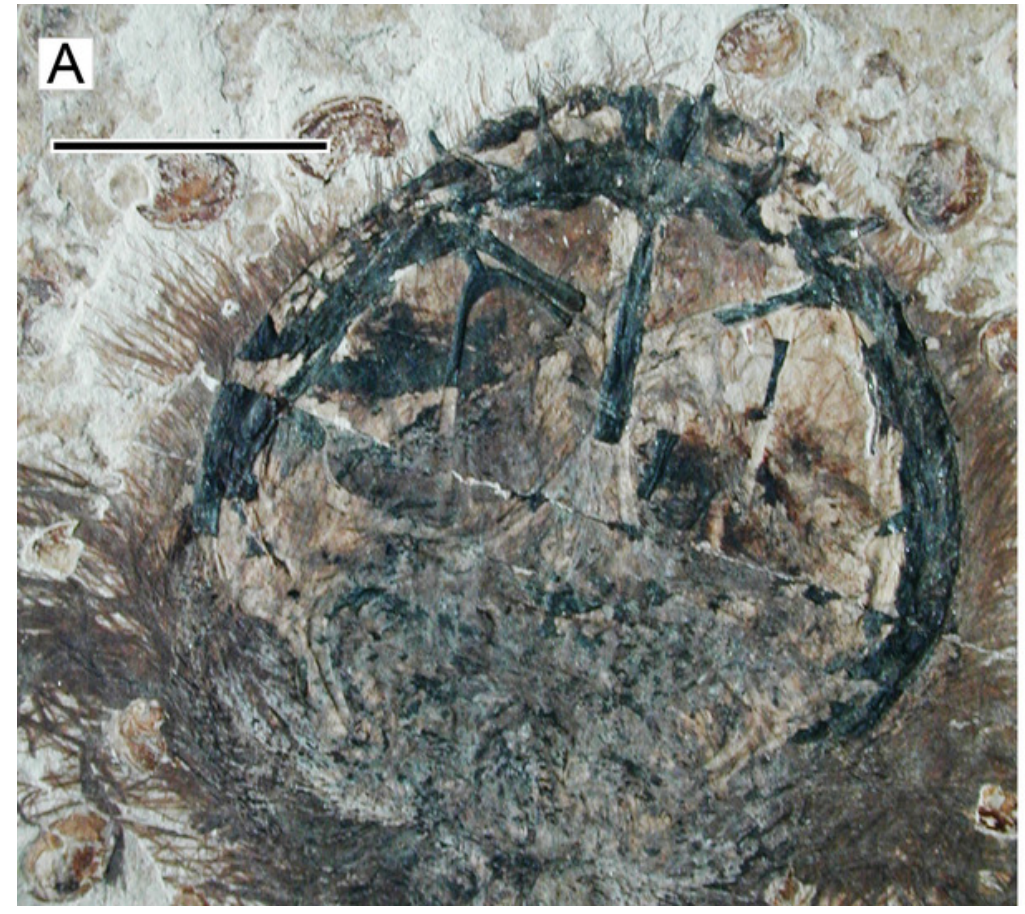

B

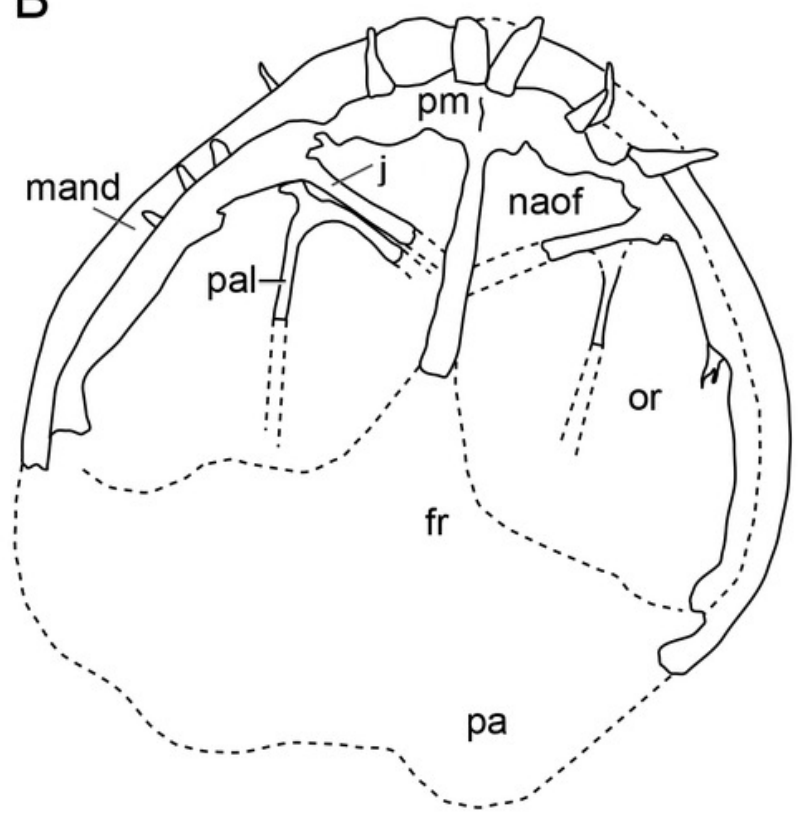


Figure 14

Figure 14. Life reconstruction of Sinomacrops bondei.

Paleoart courtesy of Zhao Chuang, reproduced with permission. 


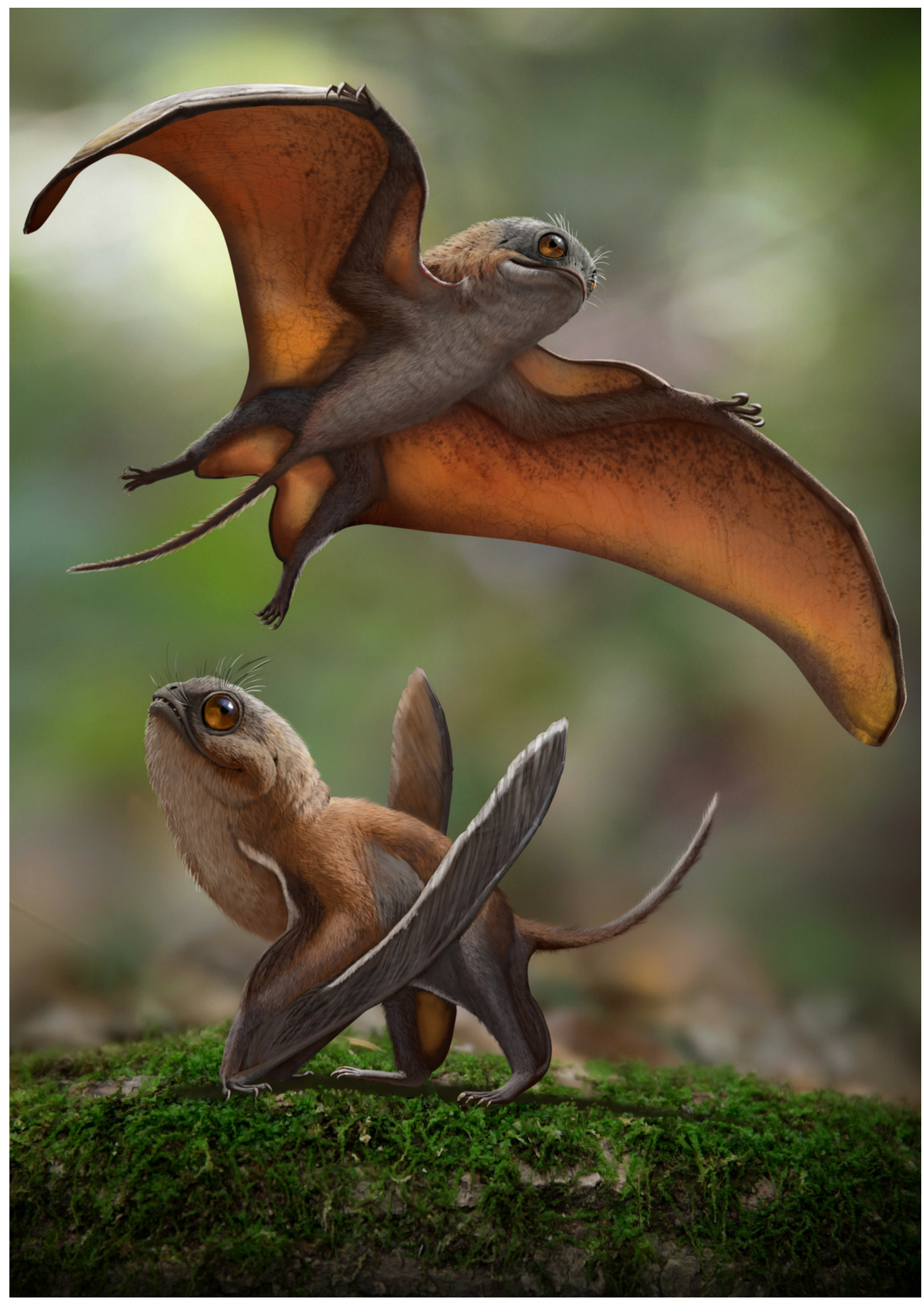

Peerj reviewing PDF | (2020:10:53890:2:0:NEW 25 Feb 2021) 


\section{Table 1 (on next page)}

Table 1. Measurements of JPM-2012-001.

Measurements are given in centimeters. Values for long bones correspond to their lengths. Interrogations mean the element is too incomplete for an informative value. Dashes mean the element is not preserved. Asterisk means the element is slightly incomplete. 


\begin{tabular}{lll} 
Element & Right & Left \\
\hline Scapula & $\sim 1.95$ & $?$ \\
\hline Coracoid & $?$ & $\sim 1.37$ \\
\hline Humerus & 2.36 & 2.39 \\
\hline Radius/ulna & 3.63 & 3.47 \\
\hline Metacarpal IV & $\sim 0.67$ & - \\
\hline Wing phalanx 1 & 4.12 & $\sim 3.84$ \\
\hline Wing phalanx 2 & 3.60 & - \\
\hline Wing phalanx 3 & 1.81 & - \\
\hline Femur & 1.36 & 1.31 \\
\hline Tibiotarsus & 2.66 & $2.53^{*}$ \\
\hline Metatarsus & $\sim 1.1$ & $\sim 1$ \\
\hline
\end{tabular}

1 Table 1. Measurements of JPM-2012-001. Measurements are given in centimeters. Values for 2 long bones correspond to their lengths. Interrogations mean the element is too incomplete for an 3 informative value. Dashes mean the element is not preserved. Asterisk means the element is 4 slightly incomplete. 


\section{Table 2 (on next page)}

Table 2. Comparative table showing skeletal element ratios among anurognathids. 


\begin{tabular}{|c|c|c|c|c|c|c|c|c|c|c|c|c|c|c|c|c|c|}
\hline Anurognathidae & $\begin{array}{l}\text { hu/m } \\
\text { cIV }\end{array}$ & $\begin{array}{l}\text { hu/f } \\
\text { e }\end{array}$ & $\begin{array}{l}\text { hu/ } \\
\text { ul }\end{array}$ & $\begin{array}{l}\mathbf{h u}+\mathbf{u} \\
\mathbf{l} / \mathbf{f e}+\mathbf{t} \\
\mathbf{i}\end{array}$ & $\begin{array}{l}\mathrm{ul} / \mathrm{mc} \\
\text { IV }\end{array}$ & $\mathrm{ul} / \mathrm{fe}$ & $\begin{array}{l}\mathrm{sc} / \mathrm{c} \\
\mathbf{o}\end{array}$ & $\begin{array}{l}\text { ph1d4 } \\
/ \text { ul+ } \\
\text { mcIV }\end{array}$ & $\begin{array}{l}\text { ph1d4 } \\
\text { / } \\
\text { ti }\end{array}$ & $\begin{array}{l}\text { ph2d4 } \\
/ \\
\text { ph1d4 }\end{array}$ & $\begin{array}{l}\text { ph3d4 } \\
/ \\
\text { ph1d4 }\end{array}$ & $\begin{array}{l}\text { ph3d4 } \\
\text { / ph2d4 }\end{array}$ & $\begin{array}{l}\text { ph4d4 } \\
\text { / ph1d4 }\end{array}$ & $\begin{array}{l}\text { fe/m } \\
\text { cV }\end{array}$ & $\mathrm{ti} / \mathrm{fe}$ & $\begin{array}{l}\mathbf{m t I I} \\
\mathbf{I} / \mathbf{t i}\end{array}$ & $\begin{array}{l}\text { caS/f } \\
\text { e }\end{array}$ \\
\hline $\begin{array}{l}\text { Anurognathus } \\
\text { ammoni } \\
\text { (holotype) }\end{array}$ & 2.91 & 1.19 & 0.70 & 1.16 & 4.18 & 1.70 & $?$ & 1.01 & 1.49 & $?$ & $?$ & $?$ & $?$ & 2.45 & 1.44 & 0.46 & 0.50 \\
\hline $\begin{array}{l}\text { Anurognathus } \\
\text { ammoni (referred) }\end{array}$ & 3.64 & 1.25 & 0.70 & 1.26 & 5.10 & 1.76 & $?$ & 0.95 & 1.44 & 0.77 & 0.44 & 0.56 & $?$ & 2.90 & 1.39 & 0.42 & $?$ \\
\hline $\begin{array}{l}\text { Vesperopterylus } \\
\text { lamadongensis }\end{array}$ & 2.75 & 1.35 & 0.74 & 1.34 & 3.73 & 1.83 & 0.97 & 0.96 & 1.64 & 0.81 & 0.60 & 0.74 & 0.12 & 2.04 & 1.37 & 0.47 & 0.59 \\
\hline $\begin{array}{l}\text { Jeholopterus } \\
\text { ningchengensis } \\
\text { (holotype) }\end{array}$ & 3.26 & 1.55 & 0.70 & 1.67 & 4.68 & 2.22 & 1.96 & 0.86 & 1.86 & 0.88 & 0.65 & 0.73 & 0.17 & 2.10 & 1.25 & 0.44 & $?$ \\
\hline $\begin{array}{l}\text { Jeholopterus } \\
\text { ningchengensis } \\
\text { (CAGS IG 02-81) }\end{array}$ & 3.39 & 1.52 & 0.78 & 1.59 & 4.03 & 1.99 & 1.28 & 0.88 & 1.88 & 0.89 & $?$ & $?$ & $?$ & 2.02 & 1.22 & 0.47 & $?$ \\
\hline $\begin{array}{l}\text { Dendrorhynchoid } \\
\text { es curvidentatus }\end{array}$ & 2.99 & 1.43 & 0.78 & 1.37 & 3.82 & 1.82 & 1.15 & 0.99 & 1.66 & 0.80 & $?$ & $?$ & $?$ & 2.4 & 1.37 & 0.45 & $?$ \\
\hline $\begin{array}{l}\text { Luopterus } \\
\text { mutoudengensis } \\
\text { holotype }\end{array}$ & 2.45 & 1.28 & 0.64 & 1.44 & 3.81 & 2.00 & 1.88 & 0.94 & 1.85 & 0.82 & 0.50 & 0.61 & 0.10 & 1.91 & 1.29 & 0.44 & $\begin{array}{l}>0.8 \\
6\end{array}$ \\
\hline NJU-57003 & 2.60 & 1.34 & 0.60 & 1.42 & 4.31 & 2.15 & 1.27 & 0.90 & 1.63 & 0.86 & 0.40 & 0.46 & 0.10 & 1.97 & 1.47 & 0.45 & 1.78 \\
\hline IVPP V16728 & $?$ & 1.43 & $?$ & $?$ & $?$ & $?$ & $?$ & $?$ & $?$ & $?$ & $?$ & $?$ & $?$ & $?$ & $\begin{array}{l}\sim 1.4 \\
0\end{array}$ & 0.38 & $\begin{array}{l}>1.4 \\
9\end{array}$ \\
\hline $\begin{array}{l}\text { Sinomacrops } \\
\text { bondei }\end{array}$ & 3.55 & 1.77 & 0.66 & 1.51 & 5.29 & 2.70 & 1.42 & 0.97 & 1.59 & 0.87 & 0.44 & 0.50 & $?$ & $\sim 2$ & 1.99 & 0.48 & $\begin{array}{l}>1.6 \\
9\end{array}$ \\
\hline $\begin{array}{l}\text { Batrachognathus } \\
\text { volans }\end{array}$ & $?$ & 1.93 & $?$ & $?$ & $?$ & $?$ & $?$ & $?$ & $?$ & $?$ & $?$ & $?$ & $?$ & $?$ & 1.75 & $?$ & $1.47^{*}$ \\
\hline
\end{tabular}

$$
1
$$

2 Table 2. Comparative table showing skeletal element ratios among anurognathids. 